\title{
Cryostratigraphy, sedimentology, and the late Quaternary evolution of the Zackenberg River delta, northeast Greenland
}

\author{
Graham L. Gilbert ${ }^{1,2}$, Stefanie Cable ${ }^{1,3}$, Christine Thiel ${ }^{4,5,6}$, Hanne H. Christiansen ${ }^{1}$, and Bo Elberling ${ }^{3}$ \\ ${ }^{1}$ Arctic Geology Department, University Centre in Svalbard, PO Box 156, 9170 Longyearbyen, Norway \\ ${ }^{2}$ Department of Earth Science, University of Bergen, Realfagbygget, Allegt. 41, 5007 Bergen, Norway \\ ${ }^{3}$ Center for Permafrost (CENPERM), Department of Geosciences and Natural Resource Management, \\ University of Copenhagen, Øster Voldgade 10, 1350 Copenhagen, Denmark \\ ${ }^{4}$ Nordic Laboratory for Luminescence Dating, Department of Earth Sciences, Aarhus University, \\ Risø Campus, 4000 Roskilde, Denmark \\ ${ }^{5}$ Centre for Nuclear Technologies (Nutech), Technical University of Denmark, Risø Campus, \\ 4000 Roskilde, Denmark \\ ${ }^{6}$ Leibniz Institute for Applied Geophysics, Section S3: Geochronology and Isotope Hydrology, \\ Stilleweg 2, 30655 Hanover, Germany
}

Correspondence to: Graham L. Gilbert (graham.gilbert@unis.no)

Received: 31 December 2016 - Discussion started: 17 January 2017

Revised: 7 April 2017 - Accepted: 1 May 2017 - Published: 30 May 2017

\begin{abstract}
The Zackenberg River delta is located in northeast Greenland $\left(74^{\circ} 30^{\prime} \mathrm{N}, 20^{\circ} 30^{\prime} \mathrm{E}\right)$ at the outlet of the Zackenberg fjord valley. The fjord-valley fill consists of a series of terraced deltaic deposits (ca. $2 \mathrm{~km}^{2}$ ) formed during relative sea-level (RSL) fall. We investigated the deposits using sedimentological and cryostratigraphic techniques together with optically stimulated luminescence (OSL) dating. We identify four facies associations in sections (4 to $22 \mathrm{~m}$ in height) exposed along the modern Zackenberg River and coast. Facies associations relate to (I) overriding glaciers, (II) retreating glaciers and quiescent glaciomarine conditions, (III) delta progradation in a fjord valley, and (IV) fluvial activity and niveo-aeolian processes. Pore, layered, and suspended cryofacies are identified in two $20 \mathrm{~m}$ deep ice-bonded sediment cores. The cryofacies distribution, together with low overall ground-ice content, indicates that permafrost is predominately epigenetic in these deposits. Fourteen OSL ages constrain the deposition of the cored deposits to between approximately 13 and $11 \mathrm{ka}$, immediately following deglaciation. The timing of permafrost aggradation was closely related to delta progradation and began following the subaerial exposure of the delta plain (ca. $11 \mathrm{ka}$ ). Our results reveal information concerning the interplay between deglaciation, RSL change, sedimentation, permafrost aggradation, and the tim-
\end{abstract}

ing of these events. These findings have implications for the timing and mode of permafrost aggradation in other fjord valleys in northeast Greenland.

\section{Introduction}

Formerly glaciated valleys and fjords are sedimentary depocentres in which large volumes of sediment have accumulated during the late Weichselian and early Holocene (Aarseth, 1997; Hansen, 2001; Eilertsen et al., 2011). Fjordvalley fills predominantly develop during highstand and relative sea-level (RSL) fall following deglaciation, when sediment yield is high and accommodation space is declining (Ballantyne, 2002; Corner, 2006). The formerly ice-covered areas of coastal Greenland experienced isostatic rebound following deglaciation (Fleming and Lambeck, 2004). This has resulted in uplifting, incision, and erosion of valley-fill deposits by Holocene fluvial and coastal activity. Recent studies have examined the deltaic infill of fjords in high-relief landscapes (Hansen, 2004; Corner, 2006; Eilertsen et al., 2011; Marchand et al., 2013). However, few of these studies were in landscapes with permafrost. Therefore, the relationship between ground ice and the depositional setting in high-relief 
landscapes has received less attention. Combining sedimentological observations with the systematic classification of ground ice provides a mechanism to correlate sedimentary facies with cryofacies - resulting in an improved palaeoenvironmental reconstruction.

Cryostratigraphy is the description, interpretation, and correlation of cryofacies and their relationship to the host deposits (French and Shur, 2010; Murton, 2013). Systematic classification of cryofacies permits the differentiation between syngenetic and epigenetic permafrost (Gilbert et al., 2016). In syngenetic settings, permafrost aggrades upwards at a rate proportional to the sedimentation rate at the ground surface. Ground ice in syngenetic permafrost primarily forms as segregated ice at the top of permafrost (Mackay, 1972). Conversely, epigenetic permafrost aggrades downwards after the deposition of the host material. Where moisture and sediment conditions permit, syngenetic permafrost contains a diverse suite of ice-rich cryofacies. Epigenetic permafrost is characteristically ice poor as the moisture source is often restricted to the surrounding sediment (French and Shur, 2010; Murton, 2013). The presence of the pore cryofacies in frost-susceptible material is characteristic of epigenetic permafrost (Stephani et al., 2014). However, ice-rich cryofacies may form in epigenetic permafrost if an external water source is available to recharge the local groundwater system (Pollard, 2000a; Kanevskiy et al., 2014). In addition to the mode of permafrost aggradation, sediment characteristics and the availability of moisture have a controlling influence on the presence and morphology of ground ice (Stephani et al., 2014). The application of cryostratigraphy to palaeo-landscape reconstruction therefore requires consideration of the physical properties of the soil, sediment, or bedrock which host ground ice.

This study reconstructs Holocene permafrost and landscape change in the Zackenberg lowlands using sedimentary and cryofacies. The objectives are (1) to describe sedimentary facies and cryofacies as observed in sections and cores, (2) to relate ground-ice formation in permafrost to sediment properties and depositional environments, and (3) to combine observations to reconstruct landscape change in the Zackenberg lowlands since the Last Glacial Maximum (LGM). This is the first study to investigate cryostratigraphy in northeast Greenland, and sheds new light on the variability of ground ice in high-relief Arctic landscapes.

\section{Regional setting}

\subsection{Glaciation, deglaciation, and relative sea-level change}

Zackenberg is located on the Wollaston Forland in northeast Greenland $\left(74^{\circ} 30^{\prime} \mathrm{N}, 20^{\circ} 30^{\prime} \mathrm{E}\right.$; Fig. 1$), 90 \mathrm{~km}$ east of the Greenland Ice Sheet margin. This region was glaciated several times during the Quaternary period (Hjort, 1981; Funder et al., 1994; Bennike et al., 2008). The last glaciation culminated in the LGM during the late Weichselian, when the Greenland Ice Sheet extended across the region (Bennike et al., 2008). Sedimentary archives and the geomorphology of the continental shelf and slope indicate that during the LGM, ca. $22 \mathrm{ka}$, grounded glacier ice extended onto the outer continental shelf (Evans et al., 2002; Ó Cofaigh et al., 2004; Winkelmann et al., 2010). Streamlined subglacial bedforms record the presence of erosive, warm-based ice streams in the major fjords and cross-shelf troughs in NE Greenland during this period. Intervening areas were covered by grounded but non-streaming ice, in some cases preserving pre-existing landforms (Funder et al., 2011). Deglaciation initiated in the coastal areas east of Young Sound between 10.1 and $11.7 \mathrm{ka}$ (Bennike et al., 2008). The inner-fjord areas were ice-free by between 9.5 and $7.5 \mathrm{ka}$. At Zackenberg, the earliest postglacial radiocarbon date from a marine fossil is $10.1 \mathrm{ka}$, suggesting the study area was ice-free by this time (Christiansen et al., 2002).

Following deglaciation, the sea inundated low-lying areas of the Zackenberg Valley. Rapid emergence is documented during the early Holocene due to postglacial crustal rebound. Regional RSL curves are reconstructed from the height of raised beach deposits using optically stimulated luminescence (OSL) dating and AMS ${ }^{14} \mathrm{C}$ dating of palaeosurfaces and marine fossils (Bennike and Weidick, 2001; Pedersen et al., 2011). Christiansen et al. (2002) reconstructed RSL changes at Zackenberg using a combination of geomorphological evidence and radiocarbon dates of marine macrofossils and terrestrial plant remains. This curve indicates a late Quaternary marine limit of ca. $40 \mathrm{~m}$ a.s.l. During the early Holocene, RSL declined rapidly, reaching present sea level by ca. 5-6 ka (Christiansen et al., 2002).

The erosional competence of ice streams during the LGM, deglaciation history, and subsequent changes in RSL have important implications for both landscape and permafrost development in Zackenberg. Erosive ice streams in the fjords removed much of the sedimentary record from previous glacial-interglacial cycles. At the same time, warm-based glaciers precluded the formation or preservation of permafrost due to frictional heat generated at the base of the sliding glacier and the trapping of geothermal heat under the ice (Humlum, 2005). The age of permafrost in the Zackenberg lowlands is likely linked to the timing of regression, as warm boundary conditions at the sea floor would have prevented permafrost aggradation.

\subsection{Climate and permafrost}

Mean annual air temperature at Zackenberg between 1996 and 2013 was $-9.0^{\circ} \mathrm{C}$. The mean annual precipitation for the same period was $219 \mathrm{~mm}$ water equivalent, of which $90 \%$ fell as snow or sleet. Sea ice covers the Young Sound between 9 and 10 months each year from late October (Hansen et al., 2008; Jensen et al., 2014). Hydrology and sediment 


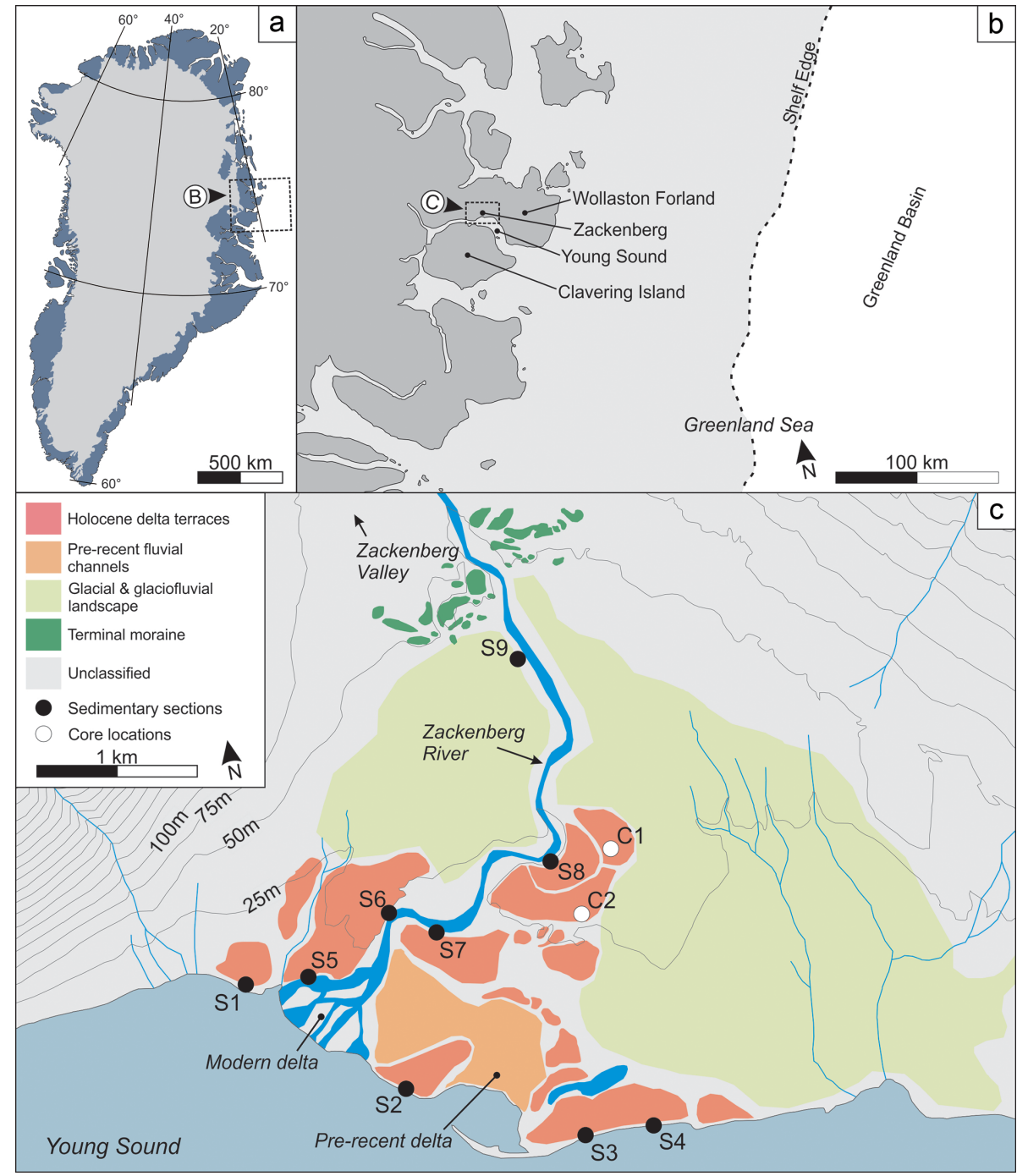

Figure 1. (a) Location of the study region in northeast Greenland. (b) Regional map of central northeast Greenland showing the location of the study area and key locations mentioned in the text. (c) Details of the study area in the Zackenberg lowlands. The glacial and glaciofluvial landscape formed during the late Weichselian, whereas the delta terraces are of late Weichselian to Holocene age. The location of sections (S1-S9) are denoted by black dots. Sediment core locations (C1 and C2) are denoted by white dots.

transport in the Zackenberg River have been summarized by Hasholt et al. (2008). The drainage basin covers an area of $512 \mathrm{~km}^{2}$, of which $20 \%$ is glaciated. Runoff in the river typically begins in June and continues until September. Sediment transport is dominated by extreme discharge events. In addition to the Zackenberg River, a number of minor rivers and streams drain the hillslopes and lowland area.

Zackenberg is located within the continuous permafrost zone. The permafrost thickness is modelled to be between 200 and $400 \mathrm{~m}$ (Christiansen et al., 2008). Ground temperatures are monitored to a depth of $20 \mathrm{~m}$ at two locations within the study area (C1 and $\mathrm{C} 2$ in Fig. 1c). Temperatures at $20 \mathrm{~m}$ depth are ca. $-6{ }^{\circ} \mathrm{C}$, with little interannual variation since monitoring began in 2012. Seasonal thaw progression and active-layer thickness has been measured since 1996 (Chris- tiansen et al., 2003). On average, the active-layer thickness varies between 70 and $80 \mathrm{~cm}$ - with topography, and its impact on the snow regime and hydrology, being the primary controlling factor (Christiansen et al., 2008).

\subsection{Geomorphology and Quaternary geology}

The Zackenberg Valley is oriented along a NW-trending fault (Koch and Haller, 1971; Nøhr-Hansen et al., 2011), separating Caledonian gneiss and granite exposed to the west in the Zackenberg Mountain (1303 m a.s.l.) from Cretaceous and Jurassic sedimentary rocks exposed to the east in the Aucellabjerg Mountain (911 m a.s.1.). The valley is ca. $8 \mathrm{~km}$ long, expanding from 2 to $7 \mathrm{~km}$ in width towards Young Sound (Fig. 1c). The lowlands are defined as the portion 
of the landscape below the early Holocene marine limit (40 $\mathrm{m}$ a.s.l.). The lowlands are primarily a relict landscape, formed by glacial, fluvial, marine, and periglacial processes during glaciation, deglaciation, and RSL decline. Glacial and glaciofluvial landforms include moraine ridges, ground moraine, meltwater plains, and raised delta terraces (Christiansen and Humlum, 1993; Christiansen et al., 2002). Permafrost landforms include ice-wedge polygons and palsas (Christiansen, 1998a; Christiansen et al., 2008).

The raised palaeo-delta at the mouth of the Zackenberg Valley covers an area of ca. $2 \mathrm{~km}^{2}$ and consists of a series of terraces. To the west, the spatial extent of the palaeo-delta is restricted by the Zackenberg Mountain. The eastern boundary is less easily defined and grades into glacial and glaciofluvial deposits. Christiansen et al. (2002) determined that the deltaic deposits began to form prior to $9.5 \mathrm{ka}$.

\section{Methods}

Data used for this study consists of sedimentological logs from nine river and coastal sections in the delta, geomorphological observations, and cryostratigraphic and sedimentological analysis of two $20 \mathrm{~m}$ long, ice-bonded sediment cores. Field data were collected over three summer field campaigns, in 2012, 2013, and 2015.

The natural exposures along the coast and river were examined to determine the sedimentary stratigraphy of the valley deposits (Figs. 1c, 2). Sections, 4 to $22 \mathrm{~m}$ high, were photographed, described, and logged in August 2015. It was not possible to describe ground-ice conditions in the sections as the rate of thaw perpendicular to the exposed surface outpaced the rate of backwasting due to erosion.

Two $20 \mathrm{~m}$ deep boreholes ( $\mathrm{C} 1$ and $\mathrm{C} 2$ ) were drilled in September 2012 using a drill rig equipped with a $42 \mathrm{~mm}$ core barrel. The sites are located within Holocene delta terraces, ca. $500 \mathrm{~m}$ apart (Fig. 1c). Core $\mathrm{C} 1$ is located at $38 \mathrm{~m}$ a.s.l. At $\mathrm{C} 1$, ca. $12 \mathrm{~m}$ of undisturbed (frozen) core was retrieved across the $20 \mathrm{~m}$ interval. Disturbed (unfrozen) material was concentrated in the unfrozen active layer and in the diamicton encountered below ca. $12 \mathrm{~m}$ depth. C2 (28 m a.s.1.) is situated at the base of a small slope, $3 \mathrm{~m}$ high. A seasonal snowbank accumulates at this site, which is located in the lee of the dominant northerly wind direction. Sand-rich surface deposits reflect nival-fluvial and aeolian sediment transport. At $\mathrm{C} 2,14 \mathrm{~m}$ of undisturbed core was recovered. Disturbed samples are spread across the length of the core with missing intervals ranging up to $4 \mathrm{~m}$ in thickness. Retrieved cores were sealed in sterile plastic bags and stored in a freezer on site. Frozen samples were transported to the University of Copenhagen for laboratory analysis.

In the laboratory, the $\mathrm{C} 1$ and $\mathrm{C} 2$ were split lengthwise, described, and photographed. Cryostructures were classified using a system adapted from Murton (2013) and French and Shur (2010). Excess ice content and gravimetric ice content were calculated for ca. 180 samples. Samples were selected to account for vertical variations in ground ice and sediment characteristics. Excess ice content $\left(E_{\mathrm{i}}, \%\right)$, the water content in excess of the pore volume upon thawing, was estimated using the volumes of saturated sediment and supernatant water using (Kokelj and Burn, 2005: Eq. 1)

$E_{\mathrm{i}}=\frac{\left(W_{\mathrm{v}} \times 1.09\right)}{\left(S_{\mathrm{v}}+\left(W_{\mathrm{v}} \times 1.09\right)\right)} \times 100$,

where $W_{\mathrm{v}}$ and $S_{\mathrm{v}}$ are the volumes of supernatant water and saturated sediment measured in a graduated beaker upon thawing, respectively, and 1.09 is used to estimate the equivalent volume of ice. Gravimetric ice content $\left(G_{\mathrm{i}}, \%\right)$, the ratio of the mass of water to the mass of dry sample, was estimated using the wet weight and dry weight of each sample using (Murton, 2013: Eq. 1)

$G_{\mathrm{i}}=\frac{\left(M_{\mathrm{i}}-M_{\mathrm{d}}\right)}{M_{\mathrm{d}}} \times 100$,

where $M_{\mathrm{i}}$ is the mass of the frozen sample and $M_{\mathrm{d}}$ is the mass of the sample following oven drying $\left(90^{\circ} \mathrm{C}, 24 \mathrm{~h}\right)$.

Reliable OSL dating ages require sufficient exposure to daylight prior to deposition in order to reset (bleach) the sediment at the time of deposition. Incomplete bleaching is potentially a problem in Arctic environments as sediments may have been transported subglacially, over short distances, or during the polar night (Fuchs and Owen, 2008; Rittenour, 2008; Alexanderson and Murray, 2012). If the sediment grains are not completely reset then OSL dating may overestimate the depositional age.

OSL dating was performed on 14 samples from depths of up to $12 \mathrm{~m}$ in material from $\mathrm{C} 1$ and $\mathrm{C} 2$. The ages are based on sand-sized quartz grains, collected and processed under subdued orange light conditions. A single-aliquot regenerative protocol (Murray and Wintle, 2000) with a preheat of $200^{\circ} \mathrm{C}$ and a cut heat of $180^{\circ} \mathrm{C}$ was applied on the fast-componentdominated fine-sand quartz. To test for incomplete bleaching, infrared-stimulated luminescence (IRSL) doses and ages $\left(\mathrm{IR}_{50}\right.$ and $\mathrm{pIRIR}_{225}$ ) were derived from feldspar samples following the protocol proposed by Buylaert et al. (2009). IR 50 refers to feldspar luminescence stimulated at $50^{\circ} \mathrm{C}$ by infrared light, and pIRIR 225 refers to feldspar luminescence stimulated at $225^{\circ} \mathrm{C}$ by infrared light after stimulation at $50^{\circ} \mathrm{C}$. In nature, the quartz luminescence signal is reset more quickly than the feldspar component. Therefore, if the quartz OSL and feldspar IRSL (in this study $\mathrm{IR}_{50}$ ) return similar ages (within $10 \%$ ), the sediment is determined to be well bleached and the quartz ages are believed to be accurate (Murray et al., 2012). The pIRIR 225 signal is more difficult to bleach than the $\mathrm{IR}_{50}$ signal (Thomsen et al., 2008; Buylaert et al., 2009) and can therefore be used in addition to identify poorly bleached sediments (Buylaert et al., 2011). In this study, the chronology is exclusively based on the quartz OSL ages. Given the distinct bleaching characteristics, the IRSL 


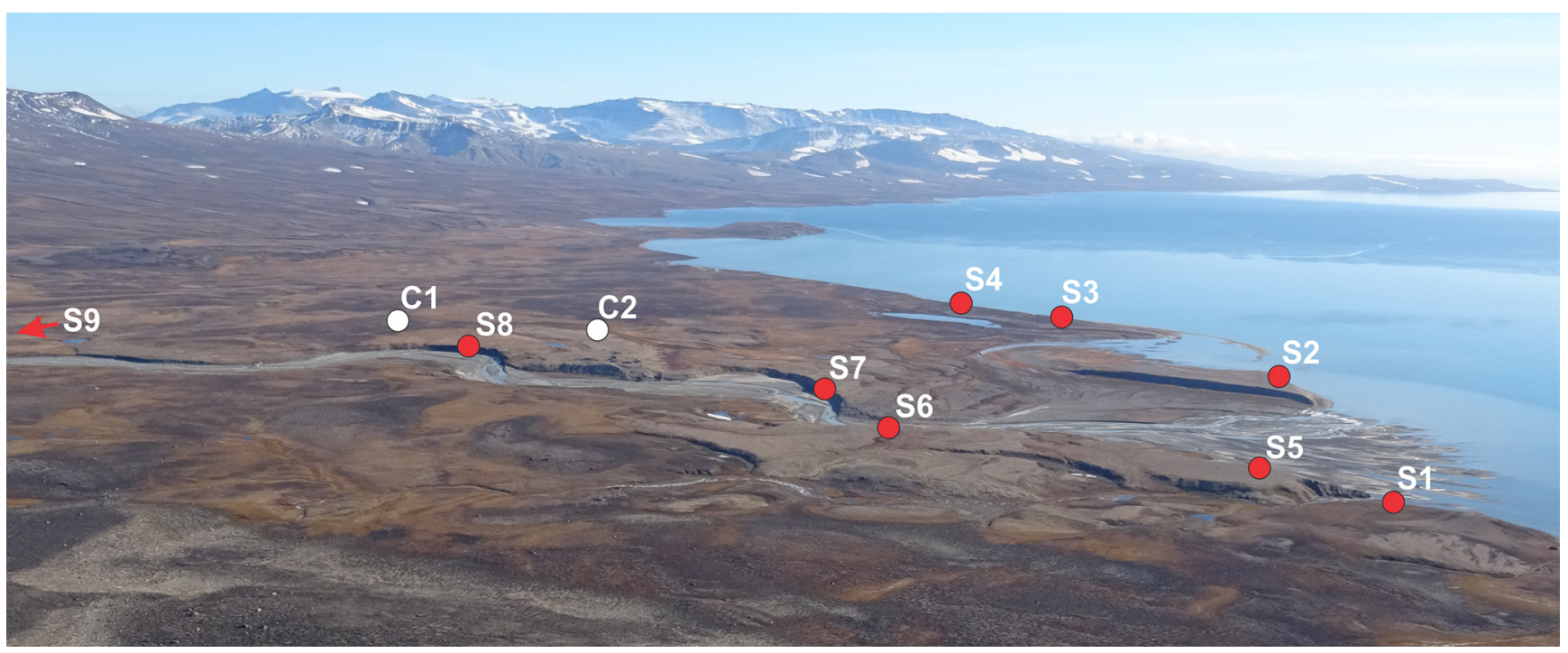

Figure 2. Overview image from the Zackenberg Mountain looking east over the lowlands on 8 September 2016. Site locations are those indicated in Fig. 1. The photo was provided by L. H. Rasmussen.

age was used to evaluate signal resetting. Samples were processed at the Nordic Laboratory for Luminescence Dating, Denmark.

\section{Description and interpretation of sedimentary facies and facies associations}

Nine sedimentary facies were identified (Table 1). These were defined based on the bulk macroscopic properties of the sediment - texture, structure, and bed boundaries. The facies ranged in lithology from a diamicton (facies 1) to silts, sands, and gravels (facies 2 to 9). Images of each facies are presented in Figs. 3 and 4. The facies were arranged into four facies associations (FA I-FA IV). Each facies association represents a distinct depositional environment. The facies associations are superpositioned in ascending order. FA I - the glacial facies association - occupies the lowermost position where present. The base of FA I was not observed. FA I is overlain by FA II and FA III. Together, FA II (the fjordbasin facies association) and FA III (the delta-slope facies association) form an upwards-coarsening succession. FA IV - the terrace top facies association - is the uppermost unit where present. The distribution of these facies associations is presented in Fig. 5.

\subsection{FA I - glacial facies association}

FA I was observed at all sites except those bordering the present-day shoreline (S1-S5). Exposures of FA I ranged up to $6 \mathrm{~m}$ in thickness and consisted of a compact, sandy, matrixsupported diamicton (facies 1). The diamicton contained angular to subrounded clasts, up to boulder size, of varying provenance. The deposits were overconsolidated when com- pared to other sedimentary facies. The lower boundary was not observed. The upper boundary to FA II was sharp and decreases in elevation, from ca. $41 \mathrm{~m}$ in the upper part of the delta to ca. $12 \mathrm{~m}$ towards the modern-day coastline (Fig. 5).

FA I is interpreted as a subglacial till on the basis of its stratigraphic position, compaction, lithology, and lateral extent (Evans and Benn, 2004). The decline in elevation of FA I towards the southeast likely reflects the increasing depth to bedrock. Widespread till deposits have previously been identified in the Zackenberg Valley bottom by Christiansen and Humlum (1993) and Christiansen et al. (2002) and outcrop at the ground surface in the glacial and glaciofluvial lowlands to the east of the delta terraces (Fig. 1). FA I was likely deposited during the last glaciation, when the Zackenberg lowlands were covered by an ice stream.

\subsection{FA II - fjord-basin facies association}

FA II includes silts (facies 2), interbedded sands and silts (facies 3), and normally graded sands and silts (facies 4). Laminated sands (facies 6) and massive sands (facies 7) are recorded in the lower portion of FA II at S6 and S7. FA II outcrops at all locations with the exception of S3, S4, and S9 (Fig. 5). Individual beds appear horizontal. The thickness of this unit ranged between 2 and $10 \mathrm{~m}$. The upper boundary is transitional when overlain by FA III and sharp and erosional when overlain by FA IV. At S6, C1, and C2, FA II initially fines upwards before an upwards coarsening into FA III (Fig. 5). At these sites, coarse-grained facies (facies 6 and 7) were observed at the base of FA II. In other sections, FA II generally fines upwards. Bioturbation was uncommon and restricted to facies 2. Macrofossils consisted of bivalve shells and shell fragments. Isolated outsized clasts were observed. 
Table 1. Sedimentary facies descriptions and interpretations.

\begin{tabular}{|c|c|c|c|}
\hline Facies & Facies description & Bed contacts and thickness & Interpretation \\
\hline $\begin{array}{l}\text { 1. Diamicton } \\
\text { (Fig. 3) }\end{array}$ & $\begin{array}{l}\text { Sandy, matrix-supported di- } \\
\text { amicton with clast-supported } \\
\text { portions. Overconsolidated } \\
\text { compared to other units. }\end{array}$ & $\begin{array}{l}\text { Lower contact is not observed, } \\
\text { upper contact is sharp. Thick- } \\
\text { ness of } 2-6 \mathrm{~m} \text { in sections and } \\
\text { cores. }\end{array}$ & $\begin{array}{l}\text { Basal till - based on compaction, } \\
\text { clast contact, position, and ex- } \\
\text { tent (Christiansen and Humlum, } \\
\text { 1993; Benn and Evans, 2010). }\end{array}$ \\
\hline $\begin{array}{l}\text { 2. Silts } \\
\text { (Fig. 4) }\end{array}$ & $\begin{array}{l}\text { Weakly laminated silts with } \\
\text { variable degrees of bioturba- } \\
\text { tion. }\end{array}$ & $\begin{array}{l}\text { Sharp or transitional contacts. } \\
\text { Up to } 1 \mathrm{~m} \text { thick. }\end{array}$ & $\begin{array}{l}\text { Fallout from suspended sediment } \\
\text { plumes and deposition by mud- } \\
\text { rich turbidity currents (Hansen, } \\
\text { 2004). }\end{array}$ \\
\hline $\begin{array}{l}\text { 3. Interlaminated sands } \\
\text { and silts } \\
\text { (Fig. 4) }\end{array}$ & $\begin{array}{l}\text { Fine sands and silts with oc- } \\
\text { casional outsized clasts. Indi- } \\
\text { vidual lamina range from } 2 \text { to } \\
20 \mathrm{~mm} \text { in thickness and may be } \\
\text { either graded or ungraded. }\end{array}$ & $\begin{array}{l}\text { Lower boundary is commonly } \\
\text { diffuse, while upper contact } \\
\text { may be sharp. Beds up to } 50 \mathrm{~cm} \\
\text { thick. }\end{array}$ & $\begin{array}{l}\text { Deposition by low-density tur- } \\
\text { bidity currents and suspended } \\
\text { sediment fallout (Reading, } \\
\text { 2009). }\end{array}$ \\
\hline $\begin{array}{l}\text { 4. Normally graded } \\
\text { sands and silts } \\
\text { (Fig. 4) }\end{array}$ & $\begin{array}{l}\text { Normally graded beds of sand } \\
\text { and silt. Some beds fine up- } \\
\text { wards into planar-parallel lami- } \\
\text { nation or ripple cross-laminated } \\
\text { sands or silts. }\end{array}$ & $\begin{array}{l}\text { Lower boundary is sharp and } \\
\text { may contain evidence of load- } \\
\text { ing, scour, or water escape. Up- } \\
\text { per boundary is gradational or } \\
\text { sharp. Beds are } 1 \text { to } 25 \mathrm{~cm} \\
\text { thick. }\end{array}$ & $\begin{array}{l}\text { Deposition by surge-like turbid- } \\
\text { ity currents (Plink-Björklund and } \\
\text { Ronnert, 1999). }\end{array}$ \\
\hline $\begin{array}{l}\text { 5. Cross-stratified } \\
\text { sands } \\
\text { (Fig. 3) }\end{array}$ & $\begin{array}{l}\text { Fine to coarse-grained sand } \\
\text { with planar cross stratification. }\end{array}$ & $\begin{array}{l}\text { Sharp, erosive base. Sharp up- } \\
\text { per contact. Beds are } 10 \text { to } \\
40 \mathrm{~cm} \text { thick. }\end{array}$ & $\begin{array}{l}\text { Deposition by unidirectional, } \\
\text { tractional currents. Cross-strata } \\
\text { record the migration of dunes } \\
\text { (Winsemann et al., 2007). }\end{array}$ \\
\hline $\begin{array}{l}\text { 6. Laminated sands } \\
\text { (Fig. 4) }\end{array}$ & $\begin{array}{l}\text { Laminated very fine to coarse } \\
\text { sands. }\end{array}$ & $\begin{array}{l}\text { Sharp lower contact. Sharp or } \\
\text { gradational upper contact. Beds } \\
\text { up to } 20 \mathrm{~cm} \text { thick. }\end{array}$ & $\begin{array}{l}\text { Deposition from sustained hy- } \\
\text { perpycnal currents subject to } \\
\text { waxing and waning (Hansen, } \\
\text { 2004). Alternatively, upper-flow } \\
\text { regime planar-parallel stratifica- } \\
\text { tion (Reading, 2009). }\end{array}$ \\
\hline $\begin{array}{l}\text { 7. Massive pebbly } \\
\text { sands } \\
\text { (Fig. 3) }\end{array}$ & $\begin{array}{l}\text { Matrix-supported pebbly sands. } \\
\text { Massive or weak inverse grad- } \\
\text { ing. Clasts are granule to pebble } \\
\text { sized. }\end{array}$ & $\begin{array}{l}\text { Sharp upper and lower contacts. } \\
\text { Beds are } 5 \text { to } 50 \mathrm{~cm} \text { thick. }\end{array}$ & $\begin{array}{l}\text { Deposition from sandy debris } \\
\text { flows (Nemec, 1990), either as } \\
\text { Gilbert-type delta foresets or flu- } \\
\text { vial channel deposits. }\end{array}$ \\
\hline $\begin{array}{l}\text { 8. Stratified pebbly } \\
\text { sands and gravels } \\
\text { (Fig. 3) }\end{array}$ & $\begin{array}{l}\text { Clast-supported gravels and } \\
\text { pebbly sands, high-angle cross } \\
\text { bedding (up to ca. } 20^{\circ} \text { ). }\end{array}$ & $\begin{array}{l}\text { Sharp, flat upper and lower con- } \\
\text { tacts. Beds are } 10 \text { to } 50 \mathrm{~cm} \\
\text { thick. }\end{array}$ & $\begin{array}{l}\text { Foreset beds deposited from } \\
\text { grain flows or noncohesive de- } \\
\text { bris flows (Plink-Björklund and } \\
\text { Ronnert, 1999; Hansen, 2004). }\end{array}$ \\
\hline $\begin{array}{l}\text { 9. Gravels } \\
\text { (Fig. 3) }\end{array}$ & $\begin{array}{l}\text { Clast-supported massive or } \\
\text { stratified gravels, with evidence } \\
\text { of imbrication. }\end{array}$ & $\begin{array}{l}\text { Sharp, flat, occasionally erosive } \\
\text { contacts. Beds are } 30 \text { to } 120 \mathrm{~cm} \\
\text { thick. }\end{array}$ & $\begin{array}{l}\text { Deposited by tractional currents } \\
\text { (Miall, 2010). Likely bedload } \\
\text { transport in a braided-river sys- } \\
\text { tem. }\end{array}$ \\
\hline
\end{tabular}

FA II is polygenetic and was deposited into a fjord environment during RSL highstand during and following deglaciation. The deposits consist of parallel-bedded fine sands and silts and reflect deposition by suspension fallout from hyperpycnal plumes and low-density turbidity currents (Table 1). The upwards fining and thinning observed at S6 and in $\mathrm{C} 1$ and $\mathrm{C} 2$ records the withdrawal of the sediment source as the ice front retreated north during deglaciation towards its grounding line at the mouth of the Zackenberg Valley (Ó Cofaigh et al., 1999). The upper portion of FA II is characterized by an upwards coarsening and thickening. This unit is interpreted as the prodelta environment. The high sand content of deposits from suspension is typical of steep, shallow-water deltas, where sand is carried beyond 

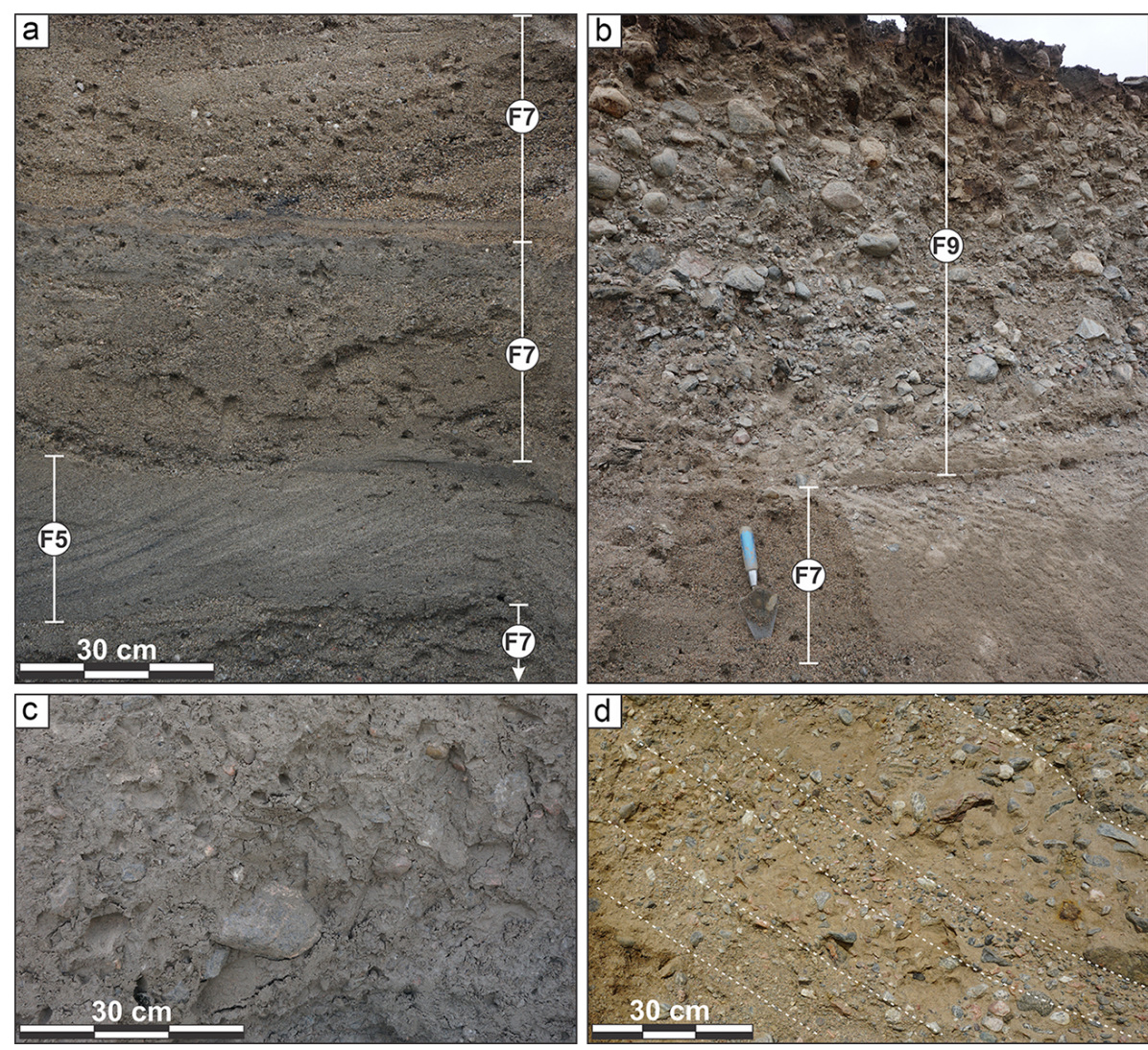

Figure 3. Coarse-grained sedimentary facies. (a) Cross-stratified sands (facies 5) and massive pebbly sands (facies 7). Image from S3 at $6 \mathrm{~m}$ a.s.l. (b) Massive gravels (facies 9) and massive pebbly sands (facies 7) at S9 (41 m a.s.1.). Note trowel is $30 \mathrm{~cm}$ in length. (c) Diamicton (facies 1) - the lowermost exposed unit at S7 (ca. 14 ma.sl.). (d) Cross-stratified gravels and pebbly sands (facies 8 ) at S6 (ca. $27 \mathrm{~m}$ a.s.1.). Individual strata are separated by dashed lines.

the delta slope by hypopycnal plumes (Corner, 2006). Turbidites record instabilities on the surrounding slopes, periods of high-river discharge, variations in glacier front position, or collapsing sediment plumes (Gilbert, 1983; Hansen, 2004). The relative absence of bioturbation and limited number of trace-making organisms indicates a stressed environment with turbid water conditions and relatively high sedimentation rates (Netto et al., 2012). Overall, the vertical changes in the relative dominance of the facies records an approaching delta front.

\subsection{FA III - delta-slope facies association}

FA III consists of interbedded sands and silts (facies 3), graded sands and silts (facies 4), laminated sands (facies 6), massive pebbly sands (facies 7), and stratified pebbly sands and gravels (facies 8). FA III is exposed at S2-S6 and in both $\mathrm{C} 1$ and $\mathrm{C} 2$. Exposures range in thickness from 2 to $10 \mathrm{~m}$ (Fig. 5). The relative influence of facies 3 and facies 4 decreases upwards as the unit coarsens and beds increase in thickness. Evidence for soft-sediment deformation is occasionally observed in association with dewatering structures. At sites S2-S6, beds dip 5-25 southeast, towards Young
Sound (Fig. 4a). Dip angles increase upwards as the beds coarsen and thicken towards the top of the exposures.

The inclined, planar beds of FA III are interpreted as foresets deposited during the progradation of a Gilbert-type delta. The overall decline in the elevation towards Young Sound indicates that this facies association was deposited during RSL fall. Variations in gain size and facies composition reflect differences in their proximity to fluvial channels, variations in discharge, and sediment transport processes. The deposits reflect suspension settling, turbidity currents, debris flows, and grain flows associated with slope failure on the delta front. Facies 7 and 8 were deposited by gravitational avalanches and debris flows following accumulation on the upper delta slope (Nemec, 1990; Plink-Björklund and Ronnert, 1999; Hansen, 2004). Facies 3, 4, and 6 record the activity of turbidity currents either due to underflow of sedimentladen river water or flow transformation (Kneller and Buckee, 2000; Winsemann et al., 2007). The presence of softsediment deformation structures and absence of bioturbation suggest a rapid sedimentation rate for FA III. 

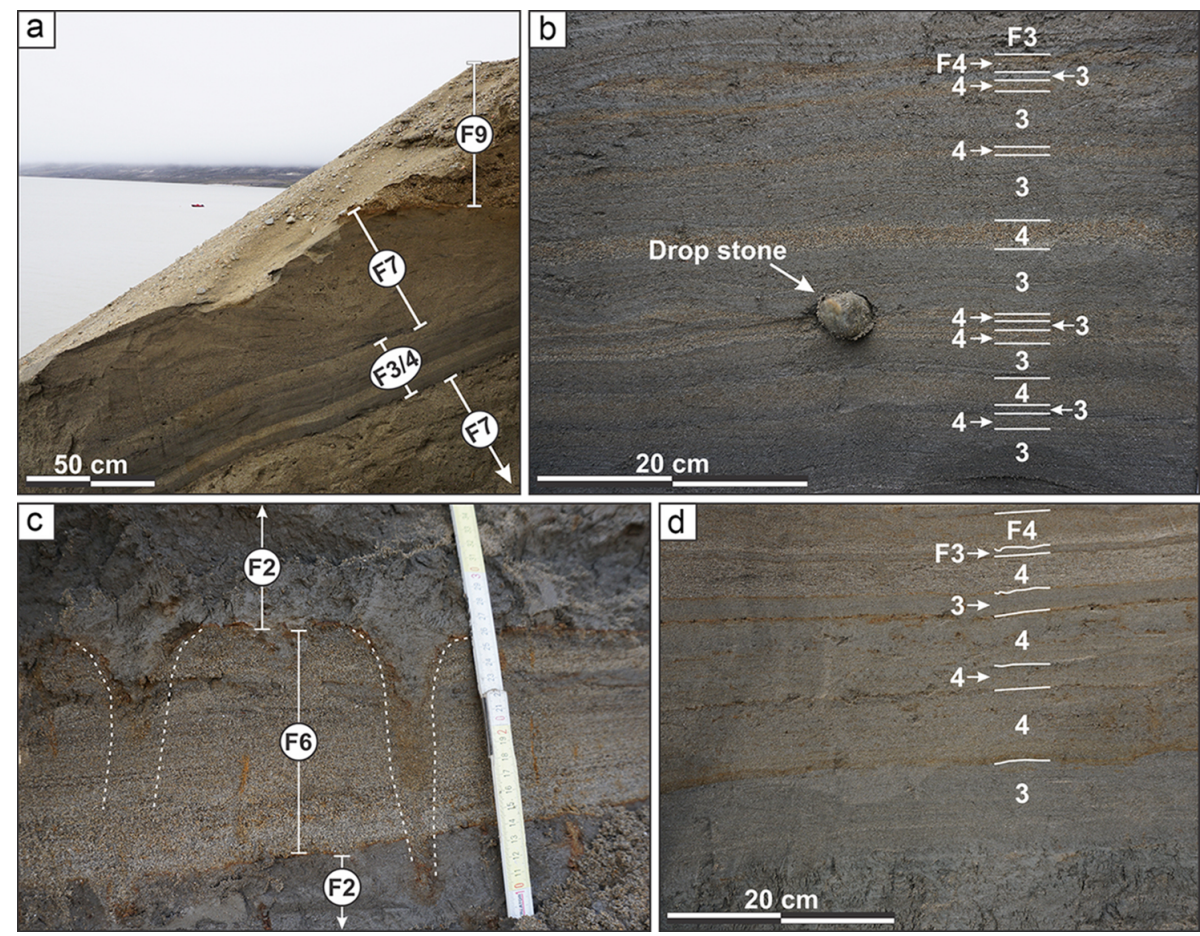

Figure 4. Fine-grained sedimentary facies. (a) Massive gravels (facies 9) truncating massive pebbly sand (facies 7), interbedded sands and silts (facies 3), and graded sands (facies 4) at S2 at $11 \mathrm{~m}$ a.s.l. (b) Alternating facies 3 and facies 4 at S5 (9 m a.s.1.). Note the presence of an outsized clast. (c) Bioturbated silts (facies 2) and laminated sands (facies 6) at S5 (6 m a.s.1.). Note vertically oriented burrows outlined with white dashed lines. (d) Alternating facies 3 and facies 4 at S2 (5 m a.s.1.).

\subsection{FA IV - terrace-top facies association}

FA IV consists of cross-stratified sands (facies 5), laminated sands (facies 6), massive pebbly sands (facies 7), and gravels (facies 9). The facies association ranges between 0.5 and $3.0 \mathrm{~m}$ in thickness and is exposed at elevations between 5 and $45 \mathrm{~m}$ a.s.l. The elevation of FA IV declines towards Young Sound both to the south and east (Fig. 5). Facies 9 increases in dominance with distance inland. FA IV has a sharp, erosive contact with the underlying unit.

FA IV is polygenetic and the component facies are related to a range of depositional processes and environments. Deposits are interpreted to primarily reflect fluvial activity associated with a deltaic distributary plain or braided-river system. Diffusely stratified gravels with imbrication (facies 9) and planar-parallel laminated sands (facies 6) indicate bedload transport by unidirectional currents of varying strength (Miall, 2010). Cross-stratified sand beds record the migration of dunes in braided-river channels or distributary systems (Miall, 2006; Winsemann et al., 2007). Massive pebbly sands (facies 7) are deposits of pseudoplastic debris flows (Miall, 2010). Secondary processes include winnowing by wind, marine reworking during RSL fall, and redistribution of sediment by snowmelt (Christiansen and Humlum, 1993; Christiansen, 1998b; Christiansen et al., 2002). FA IV devel- oped at successively lower levels during RSL fall and fluvial incision and channel migration.

\section{Cryofacies}

Three cryofacies are visually identified in $\mathrm{C} 1$ and $\mathrm{C} 2$ based on the bulk macroscopic characteristics of ground ice namely the morphological expression of ice and the proportion of ice to sediment. These cryofacies are (1) pore cryofacies (Po), (2) layered cryofacies (La), and (3) suspended cryofacies (Su). An example of each cryofacies is given in Fig. 6. In addition, disturbed sections were identified where samples were thawed during the drilling process. In these cases, ice present within the samples melted and the cryofacies were destroyed. The vertical distributions of the cryofacies and disturbed intervals are given in Figs. 7 and 8.

Po dominates at both $\mathrm{C} 1$ and $\mathrm{C} 2$. Po develops due to the in situ freezing of pore water in the spaces between mineral grains, cementing individual grains. The interstitial ice is not visible to the unaided eye. La occurs in various lithologies in both $\mathrm{C} 1$ and $\mathrm{C} 2$. Ice layers are less than $5 \mathrm{~cm}$ in thickness and may contain sediment grains or aggregates. La is observed in FA II and FA III in C1 as well as in FA III in C2. Su develops where sediment grains or aggregates are suspended in ice. The visible ice content of Su exceeds $50 \%$. Su is ob- 

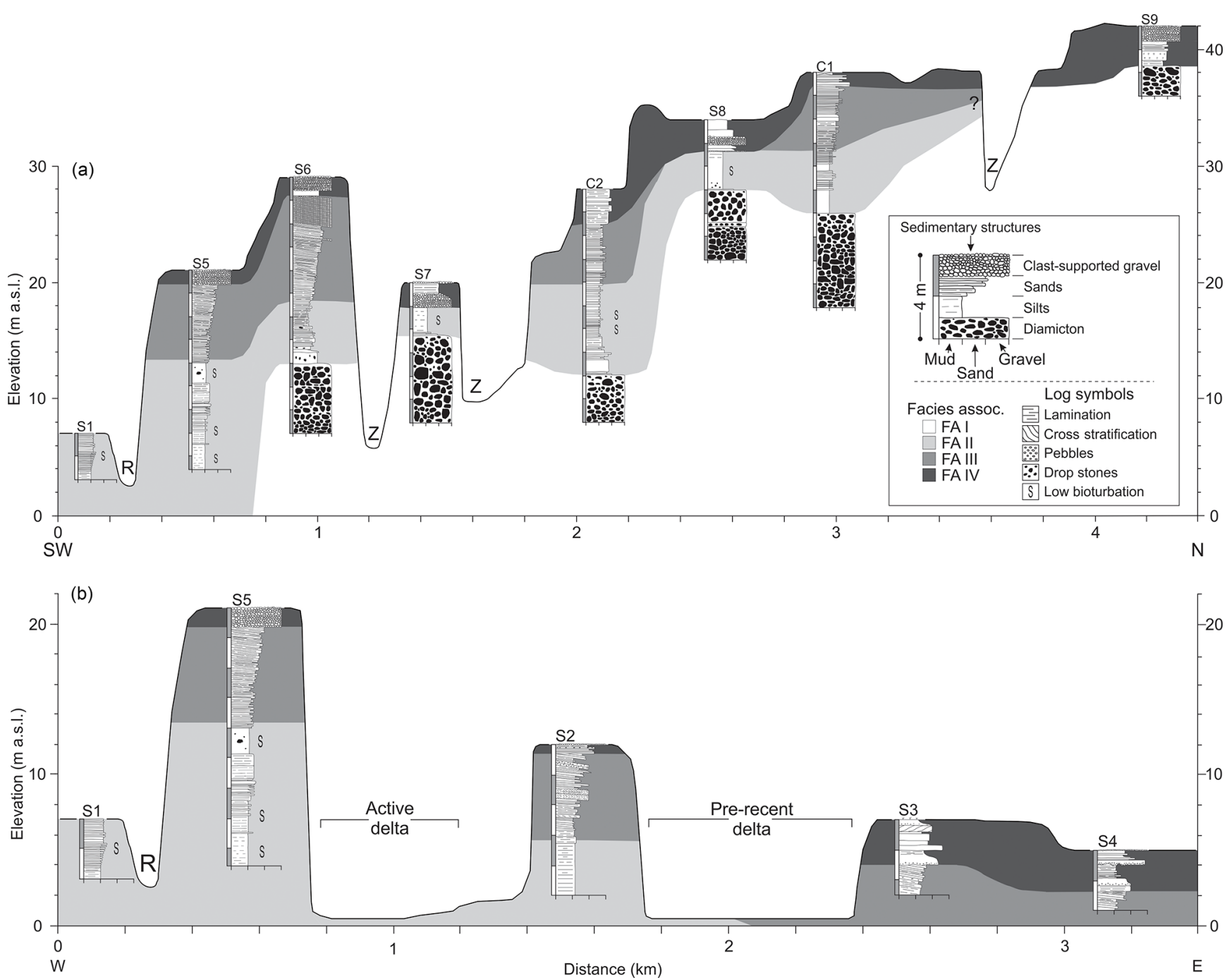

Figure 5. Correlation panel of sedimentary logs and facies associations from (a) the sections along the Zackenberg River (S1 and S5-S9) and cores (C1 and $\mathrm{C} 2$ ) and (b) coastal section (S1-S5). The site identities, above each log, correspond to those in Fig. $1 . \mathrm{Z}$ and $\mathrm{R}$ indicate the location of the Zackenberg River and minor streams, respectively.

served in FA II at $\mathrm{C} 1$. The variation between La and Su likely reflects differences in the freezing rate and availability of water during permafrost aggradation (Calmels et al., 2012). It is hypothesized that both $\mathrm{La}$ and $\mathrm{Su}$ form from the injection of pressurized water in sediment during epigenetic permafrost formation (Murton, 2013).

Ground-ice content varies with cryofacies. Gravimetric moisture content and excess ice content were highest in intervals with either La or Su. Sections with Po were devoid of excess ice and were typified by low gravimetric moisture contents. At $\mathrm{C} 1$, the gravimetric moisture content of core samples with Po ranged from 20 to $48 \%$, with no clear variation in depth. Samples from intervals with $\mathrm{La}$ and $\mathrm{Su}$ ranged from 56 to $274 \%$ (Fig. 7). Where present, excess ice content ranged from 2 to $52 \%$. At $\mathrm{C} 2$, gravimetric moisture content in samples with Po was uniformly low and ranged between
11 and $48 \%$ - no excess ice was observed in these samples (Fig. 8). One La sample containing excess ice (5\%) was obtained from $3 \mathrm{~m}$ depth ( $24 \mathrm{~m}$ a.s.l.) in C2. Analysis of disturbed sections was not conducted as the natural moisture content was altered during drilling.

\section{Geochronology}

Six OSL samples were analysed from C1 (Table 2). There are discrepancies between the OSL and $\mathrm{IR}_{50}$ ages and between the $\mathrm{IR}_{50}$ and pIRIR 225 ages for most samples. It is therefore not possible to entirely exclude incomplete bleaching at this site. Sample 131548 (32.8 m a.s.l.) is an exception to this as the OSL and $\mathrm{IR}_{50}$ ages are in close agreement $( \pm 10 \%)$. Nevertheless, the entire core sequence reflects a short time span, ranging from $11.9 \pm 0.7 \mathrm{ka}$ (sample $131543 ; 37.3 \mathrm{~m}$ a.s.l.) to 
Table 2. Summary of core samples for luminescence dating, depths, quartz OSL, and feldspar IRSL equivalent doses (De) and ages. The feldspar doses and ages are based on the measurements of three aliquots per sample and are only used to check for incomplete signal resetting. The quartz ages are the basis for the chronologies of the sediment cores. $n$ is the number of aliquots. SE is the standard error. IR ${ }_{50}$ is the feldspar luminescence stimulated at $50^{\circ} \mathrm{C}$ by infrared light. pIRIR 225 is the feldspar luminescence stimulated at $225^{\circ} \mathrm{C}$ after stimulation at $50^{\circ} \mathrm{C}$.

\begin{tabular}{|c|c|c|c|c|c|c|c|c|c|c|}
\hline \multirow[t]{2}{*}{ Site } & \multirow{2}{*}{$\begin{array}{l}\text { Laboratory } \\
\text { ID }\end{array}$} & \multirow{2}{*}{$\begin{array}{l}\text { Depth } \\
\text { (ma.s.1.) }\end{array}$} & \multirow[t]{2}{*}{ FA } & \multicolumn{3}{|c|}{ Quartz OSL } & \multicolumn{4}{|c|}{ Feldspar IRSL } \\
\hline & & & & $n$ & $\begin{array}{l}\mathrm{De} \pm \mathrm{SE} \\
(\mathrm{Gy})\end{array}$ & $\begin{array}{l}\text { Age } \pm S E \\
\text { (ka) }\end{array}$ & $\begin{array}{l}\mathrm{IR}_{50} \mathrm{De} \\
\pm \mathrm{SE}(\mathrm{Gy})\end{array}$ & $\begin{array}{l}\mathrm{pIRIR}_{225} \\
\mathrm{De} \\
\pm \mathrm{SE}(\mathrm{Gy})\end{array}$ & $\begin{array}{l}\mathrm{IR}_{50} \text { age } \\
\pm \mathrm{SE}(\mathrm{ka})\end{array}$ & $\begin{array}{l}\text { pIRIR }_{225} \\
\text { age } \\
\pm \mathrm{SE}(\mathrm{ka})\end{array}$ \\
\hline \multirow[t]{6}{*}{$\mathrm{C} 1$} & 131543 & 37.3 & IV & 20 & $29.8 \pm 1.1$ & $11.9 \pm 0.7$ & $46 \pm 5$ & $103 \pm 9$ & $15 \pm 2$ & $34 \pm 3$ \\
\hline & 131544 & 36.3 & III & 18 & $32.1 \pm 0.7$ & $11.9 \pm 1.2$ & $58 \pm 2$ & $156 \pm 9$ & $18 \pm 2$ & $48 \pm 5$ \\
\hline & 131547 & 33.4 & III & 18 & $35 \pm 2$ & $12.6 \pm 0.8$ & $55.8 \pm 0.8$ & $145 \pm 6$ & $16.6 \pm 0.7$ & $43 \pm 3$ \\
\hline & 131548 & 32.8 & III & 18 & $45 \pm 2$ & $12.4 \pm 0.7$ & $56 \pm 4$ & $155 \pm 8$ & $13.4 \pm 1.1$ & $37 \pm 3$ \\
\hline & 131550 & 31.0 & II & 20 & $47 \pm 4$ & $12.9 \pm 1.3$ & $80 \pm 9$ & $205 \pm 32$ & $19 \pm 2$ & $49 \pm 8$ \\
\hline & 131552 & 29.7 & II & 20 & $38 \pm 4$ & $13 \pm 2$ & $67 \pm 4$ & $175 \pm 12$ & $19 \pm 2$ & $50 \pm 6$ \\
\hline \multirow[t]{8}{*}{$\mathrm{C} 2$} & 131554 & 27.1 & IV & 18 & $4.3 \pm 0.2$ & $1.6 \pm 0.1$ & $3.7 \pm 0.2$ & $8.6 \pm 0.1$ & $1.2 \pm 0.1$ & $2.7 \pm 0.1$ \\
\hline & 131555 & 26.9 & IV & 18 & $14.9 \pm 1.1$ & $7.4 \pm 0.7$ & $14.8 \pm 0.3$ & $22 \pm 4$ & $5.8 \pm 0.3$ & $9 \pm 2$ \\
\hline & 131556 & 26.3 & IV & 18 & $23.9 \pm 0.7$ & $9.7 \pm 0.5$ & $20 \pm 2$ & $41 \pm 7$ & $6.5 \pm 0.6$ & $14 \pm 2$ \\
\hline & 131557 & 26.1 & IV & 18 & $25.8 \pm 1.0$ & $10.3 \pm 0.6$ & $20.4 \pm 0.8$ & $41 \pm 2$ & $6.7 \pm 0.4$ & $13.4 \pm 0.9$ \\
\hline & 131558 & 25.3 & IV & 18 & $26.6 \pm 1.3$ & $11.8 \pm 0.8$ & $28.9 \pm 0.6$ & $85 \pm 8$ & $10.3 \pm 0.5$ & $30 \pm 3$ \\
\hline & 131560 & 23.7 & III & 18 & $31.7 \pm 1.0$ & $11.7 \pm 0.6$ & $38 \pm 2$ & $115 \pm 7$ & $11.6 \pm 0.7$ & $36 \pm 3$ \\
\hline & 131561 & 18.7 & II & 18 & $25.9 \pm 1.0$ & $10.6 \pm 0.6$ & $34 \pm 3$ & $107 \pm 9$ & $11.4 \pm 1.0$ & $36 \pm 3$ \\
\hline & 131562 & 16.5 & II & 18 & $39.2 \pm 1.0$ & $12.0 \pm 0.7$ & $39.0 \pm 0.9$ & $126 \pm 6$ & $10.3 \pm 0.5$ & $33 \pm 2$ \\
\hline
\end{tabular}
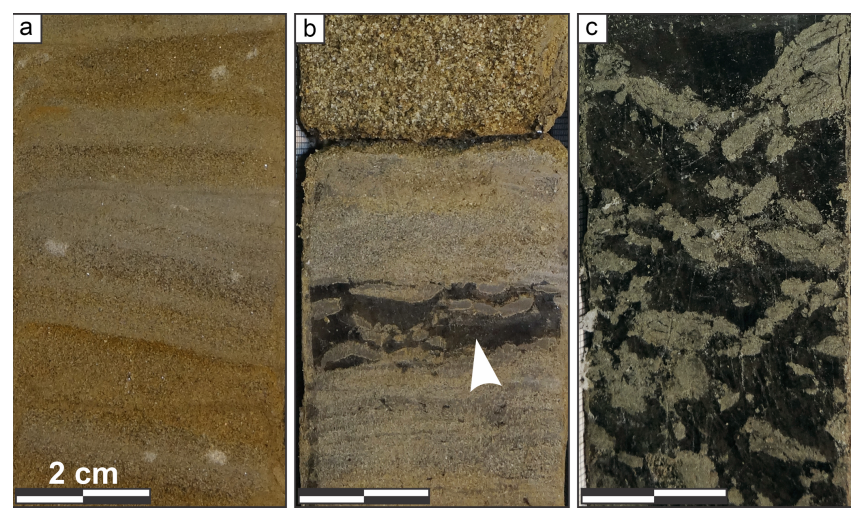

Figure 6. Cryofacies. (a) Pore (Po) cryofacies. (b) Layered (La) cryofacies indicated by the white arrow. (c) Suspended ( $\mathrm{Su}$ ) cryofacies. Note the ice appears black in the images.

$13 \pm 2 \mathrm{ka}$ (sample $131552 ; 29.7 \mathrm{~m}$ a.s.1.). The ages are similar and within the error margins, indicating that the sampled interval at $\mathrm{C} 1$ was likely deposited between ca. 13 and $12 \mathrm{ka}$ (Fig. 7).

In comparison with $\mathrm{C} 1$, the eight samples taken from $\mathrm{C} 2$ show a clearer age trend with depth (Fig. 8). The lowermost six samples at C2 (below $26 \mathrm{~m}$ a.s.1.) indicate that the sediments were deposited between 12 and $10 \mathrm{ka}$. However, the two uppermost samples are considerably younger - suggesting that the site continued to aggrade during the Holocene. Continued deposition likely relates to localized nival-aeolian processes (Christiansen, 1998b). In general, the OSL and $\mathrm{IR}_{50}$ ages at $\mathrm{C} 2$ are in good agreement, while the pIRIR $_{225}$ ages provide an age overestimate. This indicates that the bleaching time was long enough to reset the OSL and $\mathrm{IR}_{50}$ signals but not the pIRIR 225 signal (Murray et al., 2012). The overestimate of the pIRIR 225 signal may also originate from the larger residual found in any post-IR IRSL signal (Buylaert et al., 2011). The agreement of the OSL and $\mathrm{IR}_{50}$ ages indicates that there is little or no incomplete bleaching at $\mathrm{C} 2$ and that the OSL ages are accurate.

The OSL results of the 14 samples from $\mathrm{C} 1$ and $\mathrm{C} 2$ indicate a late Weichselian to early Holocene depositional age of the sediment in FA II, FA III, and FA IV. These results suggest that the majority of the sedimentation in the valley bottom took place in a narrow time interval following deglaciation (between 13 and $11 \mathrm{ka}$ ). The OSL ages are supported by Christiansen et al. (2002), who presented ${ }^{14} \mathrm{C}$ AMS dating results for samples from S5 that suggest the fjord-basin deposits were aggrading at approximately $10.1 \mathrm{ka}$.

\section{Discussion}

\subsection{Permafrost aggradation}

Few studies have examined the relationship between groundice characteristics and postglacial landscape development in Greenland (Gilbert et al., 2016). Pollard and Bell (1998), however, presented a model for ground-ice aggradation 

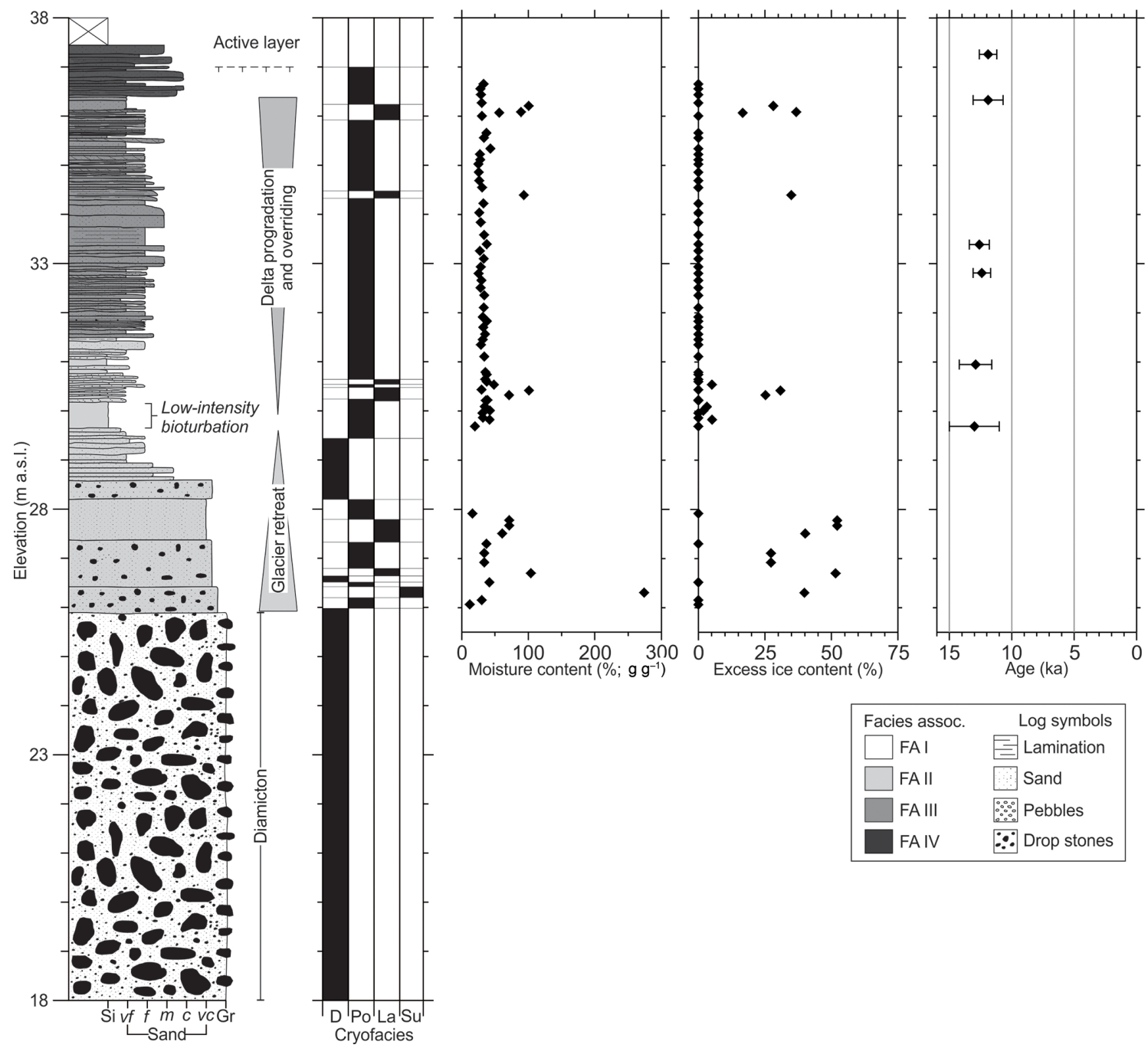

Figure 7. Log for C1 illustrating vertical variations in sediment grain size, facies associations, ground-ice characteristics and OSL ages. D, Po, La, and Su denote disturbed sections, pore, layered, and suspended cryofacies, respectively.

within epigenetic permafrost below the Holocene marine limit in the Eureka Sound lowlands on the Fosheim Peninsula in high-Arctic Canada. Here, the nature and distribution of ground ice was related to RSL change, sediment grain size, and epigenetic permafrost aggradation. On the Fosheim Peninsula, massive intrasedimental ice bodies are observed at the contact between marine silts and underlying gravels and sands, deposited during transgression. Low hydraulic conductivities in the overlying fine-grained sediments did not permit sufficient water migration resulting in the formation of reticulate, layered, lenticular, and pore cryofacies (Pollard, 2000a). Massive ice bodies and cryofacies were interpreted to have formed during and following deglaciation, when glacier meltwater and brackish sea water were available to recharge local groundwater systems (Pollard, 2000b).

$\mathrm{C} 1$ and $\mathrm{C} 2$ are generally ice poor and the majority of the cores are characterized by the pore cryofacies. Cryofacies with visible ice ( $\mathrm{La}$ and $\mathrm{Su}$ ) are restricted to the fjord-basin and delta-slope facies associations. A similar pattern is observed in gravimetric moisture content and excess ice content (Figs. 7, 8). The distribution of ground ice in the Zackenberg River delta is similar to that described by Pollard (2000a, b). The presence of the layered cryofacies in epigenetic permafrost has also been described by Kanevskiy et al. (2014) in lacustrine sediments in interior Alaska. The suspended cryofacies is likely a more developed form of the layered cryofacies, forming during increased moisture availability or slower rates of freezing. The absence of appreciable ground ice in the remainder of the core indicates that permafrost in the $\mathrm{Za}$ ckenberg lowlands is primarily epigenetic and formed following sea-level fall during the early Holocene. The differences in ice content and cryofacies between $\mathrm{C} 1$ and $\mathrm{C} 2$ likely relate to either variations in site-specific moisture availabil- 

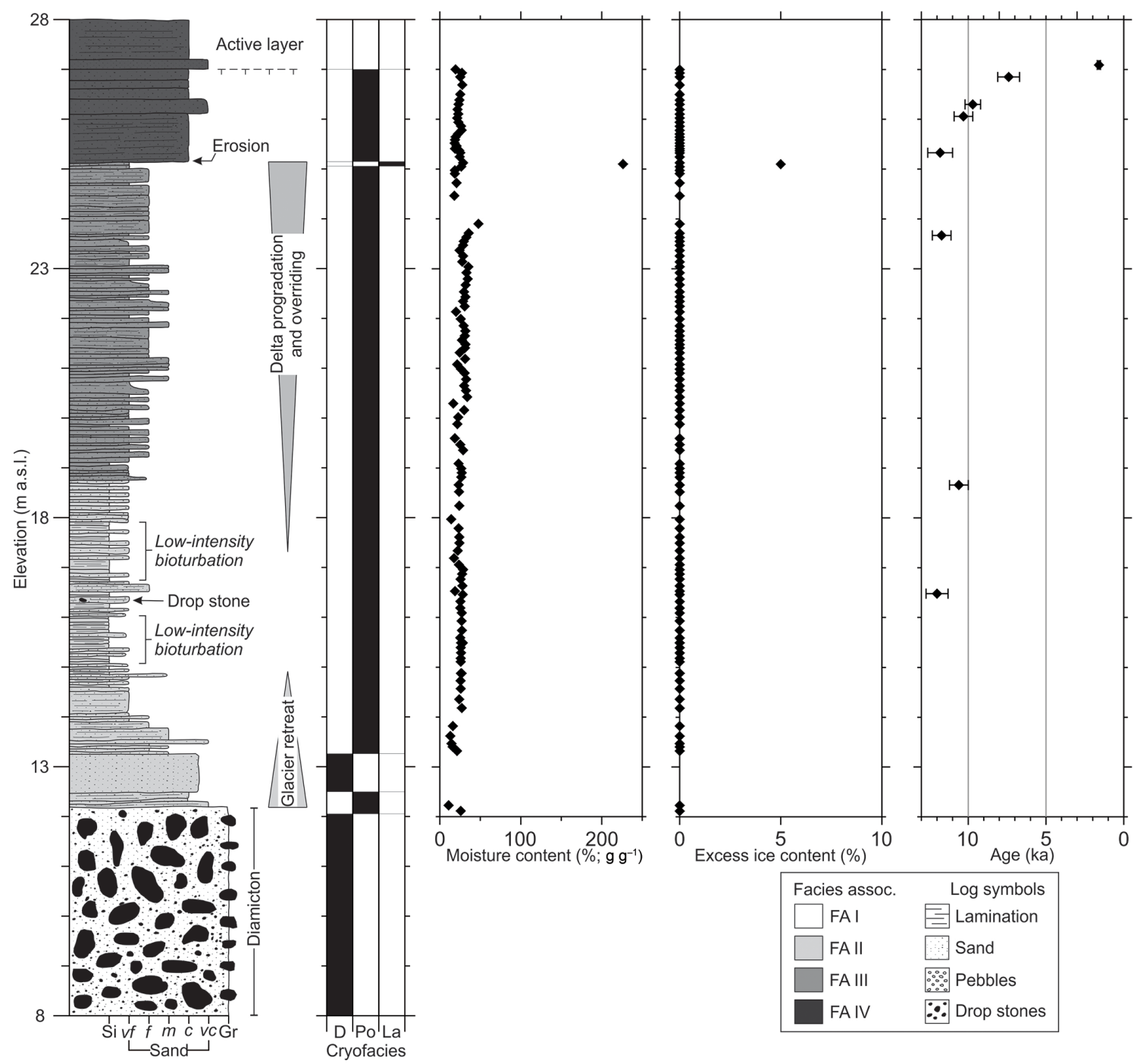

Figure 8. Log for C2 illustrating vertical variations in sediment grain size, facies associations, ground-ice characteristics, and OSL ages. D, Po, and La denote disturbed sections, pore, and layered cryofacies, respectively. Note the difference in axis range compared with Fig. 7.

ity during permafrost aggradation or lateral variations in sediment characteristics that are unresolvable at the core scale.

The presence of syngenetic permafrost is inferred using a combination of sedimentology and the dating results in the top of $\mathrm{C} 2$ - which record continued sedimentation following subaerial exposure. Here, the development of syngenetic permafrost is related to localized accumulation of niveo-aeolian sediments and organic material (Christiansen, 1998b; Christiansen et al., 2002). The uppermost syngenetic component in FA IV is almost $3 \mathrm{~m}$ in thickness. Despite continuous sedimentation and sufficient moisture availability, syngenetic permafrost at $\mathrm{C} 2$ consists of pore cryofacies. This is attributed to the coarse-grained sediment and the absence of frost-susceptible silts. Syngenetic permafrost is thus of local occurrence on the palaeo-delta surface and relates to periglacial, nival, fluvial, and aeolian activity during the Holocene.

\subsection{Valley-fill history and delta progradation}

During the past $13 \mathrm{ka}$, the Zackenberg lowlands have undergone major environmental changes through periods of glacial, marine, fluvial, and periglacial dominance. Sedimentological, cryostratigraphic, and geomorphological observations are combined with the OSL dating results to produce a model for the landscape and permafrost development of the Zackenberg lowlands. This model is condensed into three stages - illustrating the major changes in sediment supply, sea level, and sedimentary processes following glaciation (Fig. 9). The model provides a framework in which to discuss changes in the sedimentary facies and cryostratigraphy and improves our understanding of the amount of ground ice 
(a) Late Weichselian (ca. $12.5 \mathrm{ka}$ )

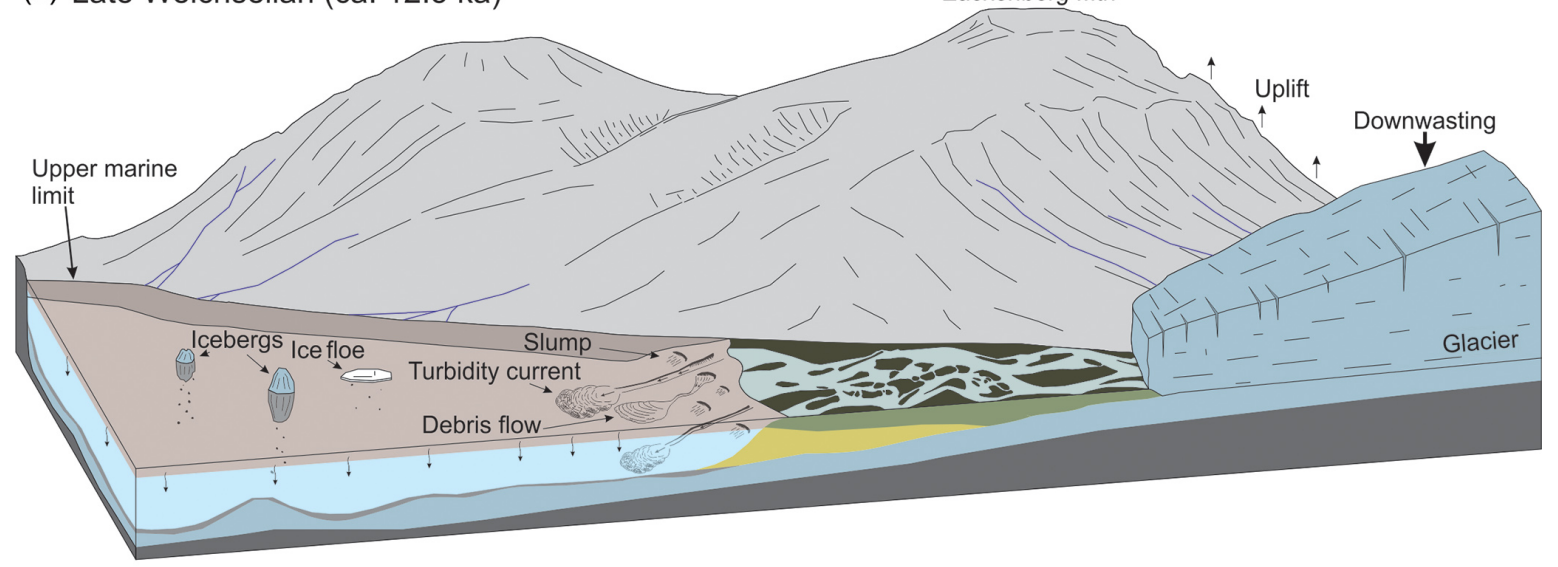

(b) Early Holocene (ca. $11 \mathrm{ka}$ )

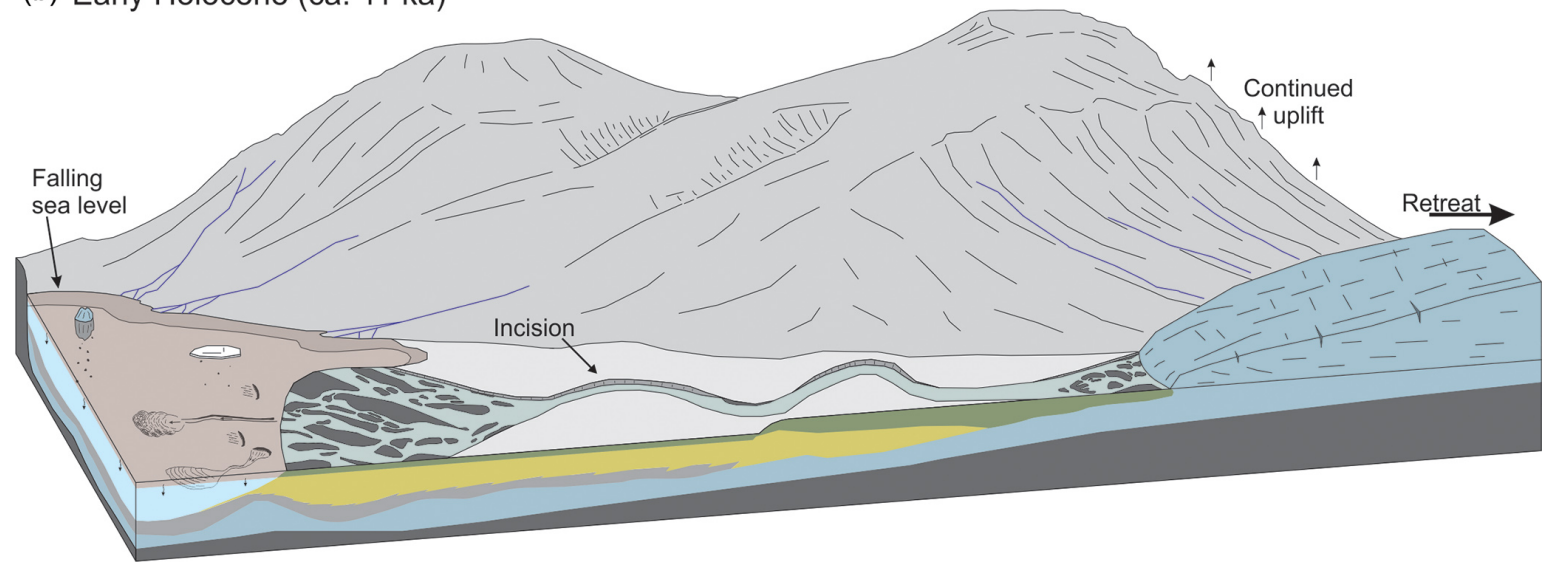

(c) Late Holocene (present)

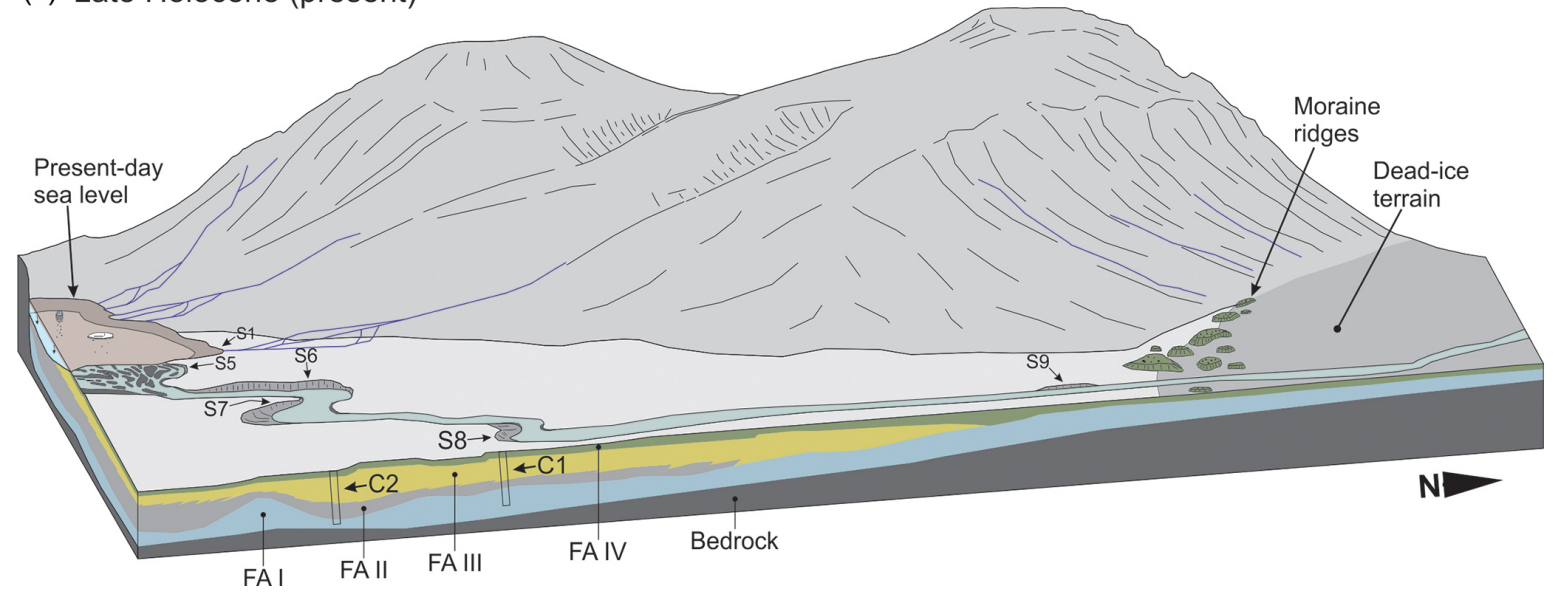

Figure 9. Schematic model of the three main stages of landscape development of the Zackenberg River delta and adjacent lowlands. The model illustrates the essential processes and sediment sources which contributed to the development of the valley-fill deposits. (a) Late Weichselian deglaciation and inundation. Sediment was supplied by a proximal glacier and by mobilization of glacial deposits by contemporary fluvial networks. (b) Early Holocene sea-level fall and areal deglaciation. High sedimentation rates and rapid delta progradation during sea-level fall. Sediment supplied primarily through the reworking of deposits by glaciofluvial erosion and incision during isostatic uplift. The landscape is slowly dissected by a meandering braided-river system resulting in the terracing observed in the landscape today. Locally, permafrost began to aggrade in the lowlands following subaerial exposure. (c) Modern landscape with select sections and coring locations. Sediment supplied by the fluvial reworking of raised deposits. Permafrost is continuous under stable, exposed land surfaces. 
in Arctic valleys. This is important as the amount of ground ice determines the potential landscape response due to climate change.

A stratigraphic model for fjord-valley infilling in Norway has been presented by Corner (2006). This tripartite model consists of a deglacial transgressive systems tract (DTST), a deglacial highstand systems tract (DHST), and a postglacial forced-regressive systems tract (PRST). The DTST is deposited during deglaciation by retrogradational stacking of proglacial sediments. Sedimentation is concurrent with marine inundation and the early stages of sea-level fall during isostatic rebound. The DHST is characterized by the rapid progradation of glaciofluvial deltas and concurrent deposition of glaciomarine deposits on the basin floor. Lastly, the PRST forms following areal deglaciation and is characterized by fluvial delta progradation, fluvial incision, and terracing during RSL fall. A similar model was developed for the Scoresby Sound region, ca. $750 \mathrm{~km}$ south of the Zackenberg area, by Hansen (2004). Though the details of the stratigraphy vary between locations, the underlying controls identified in these models - sediment supply, accommodation space, and RSL change - remain the same.

\subsubsection{Deglaciation and sea-level highstand}

The regional glaciation during the LGM is recorded by a presence of a basal till in FA I (Christiansen and Humlum, 1993; Christiansen et al., 2008). Though earlier studies have suggested a deglaciation age of 11.7 to $10.1 \mathrm{ka}$ (Bennike and Weidick, 2001; Bennike et al., 2008), the results of this investigation indicate that the Zackenberg lowlands may have been ice-free as early as 13 to $11 \mathrm{ka}$ (Table 2; Figs. 7 and 8). This discrepancy may be because previous studies have relied on radiocarbon dating of marine macrofossils. Environmental restrictions on the organisms which produce these shells such as brackish water, high sedimentation rates, and suspended sediment concentrations may have restricted their presence during deglaciation (Netto et al., 2012). However, given the errors associated with OSL ages, it is not possible to conclude this with certainty. Ice retreated initially to a grounding line in the Zackenberg Valley, depositing an endmoraine complex (Figs. 1c, 9a).

Following deglaciation of the Young Sound, the Zackenberg lowlands were inundated by the sea. The maximum flooding surface corresponds with the transition from glacial (FA I) to glaciomarine (FA II) deposits. This stratigraphic boundary marks the maximum landward incursion of marine-influenced deposits following deglaciation (Hansen, 2004). At Zackenberg, the transition from the DTST to DHST is only observed at three locations ( $\mathrm{S} 6, \mathrm{C} 1$, and $\mathrm{C} 2$ ) and is marked at the transition from upwards fining to upwards coarsening in FA II (Fig. 5). Marchand et al. (2013) observed a similar transition in the deposits of the Matane River valley (Québec, Canada), noting a reduction in icerafted debris in the non-glacially influenced facies. The scarcity of drop stones in most of FA II and FA III suggests that areal deglaciation started shortly after the transition to FA II. The OSL dates from $\mathrm{C} 1$ and $\mathrm{C} 2$ suggest that this transition was 13-11 ka.

During the DHST, the basin received sediment from suspension plumes and low-density turbidity currents contributing to the aggradation of FA II. A shallow-water highstand delta likely developed in front of a proglacial meltwater plain during this period. Deltaic deposits were not observed north of C1. Permafrost was likely absent in the lowlands during the DTST and DHST as thermal boundary conditions in the marine environment and beneath the unstable braided-river channels were too warm to permit permafrost aggradation.

\subsubsection{Delta progradation and relative sea-level fall}

RSL fell during the Holocene and reached its present-day limit ca. 4.5 ka (Bennike et al., 2008; Pedersen et al., 2011). The topography of the glacial and glaciofluvial landscape deposited during the DTST and DHST controlled the delta location. To the east, the adjacent lowlands (ca. $30-40 \mathrm{~m}$ a.s.l.) are higher in elevation than the pre-delta terrain surface. The delta was thus deposited in the lowest part of the landscape. During sea-level recession, river networks were directed to the west of the glacial and glaciofuvial deposits, where the deltaic deposits are located today (Figs. 1c, 9b). The OSL ages from the upper part of the delta in $\mathrm{C} 1$ and $\mathrm{C} 2$ constrain the timing of initial delta deposition to between 13 and $11 \mathrm{ka}$ (Table 2). Christiansen et al. (2002) presented dating results indicating that the delta was active at S5, ca. $10.1 \mathrm{ka}$.

Most of the sediments comprising FA II, FA III, and FA IV were deposited during the PRST. During this period, RSL was in decline, resulting in a reduction in accommodation space in the basin. Areal deglaciation reduced fluvial discharge and the available sediment to that which could be mobilized and reworked by the palaeo-river system (Christiansen and Humlum, 1993). Progradation of the delta continued during the PRST, but the rate of progradation was probably slower than during the DHST due to the factors mentioned above (Corner, 2006; Eilertsen et al., 2006). Despite the declining accommodation space, the sedimentary facies of FA III at the fjord-proximal sites (S1-S6) reflect deeper water conditions, as the delta prograded into the basin (Eilertsen et al., 2011).

The rapid incision of the Zackenberg River during Holocene sea-level decline limited the erosion of the underlying facies, forming the terraces and exposures documented in this study. FA IV records variable hydraulic conditions in the palaeo-Zackenberg River. At S9, FA IV was deposited at part of a large glaciofluvial outwash plain, where sediment was primarily transported as bedload. The river switched to a single-channel system with mixed sediment transport once incision began ca. $9.5 \mathrm{ka}$. This could be explained by the exhaustion of the sediment source once the glacier retreated (Marchand et al., 2013). 
Permafrost began to aggrade in the lowlands following sea-level decline and delta progradation in the late Weichselian or early Holocene. This is reflected in the assemblage of cryofacies, indicating epigenetic permafrost formation. The formation of the La and Su cryofacies in FA II and FA III was likely facilitated by glacier meltwater or seawater incursion that provided a moisture source for excess ice development. Permafrost landforms, such as ice-wedge polygons, and podsols also began to form during this time (Christiansen et al., 2002, 2008).

\subsubsection{Present delta system}

The final stage of delta formation encompasses the period of relatively stable sea level after $4.5 \mathrm{ka}$. Landscape changes after this time were minor compared to those during sealevel fall. The raised terraces reflect shifting zones of erosion and deposition during the PRST and Holocene emergence. The progradation rate of the delta declined as availability was restricted and the delta approached the edge of the Young Sound. Sediments in the drainage basin consist of mainly periglacial and glaciofluvial deposits. Late Weichselian glacial deposits have primarily been reworked (Fig. 9c). Deep incision during RSL fall limited erosion, preserving the terrace morphology.

Ice-wedge polygons formed and periglacial nivation processes have been active in the delta since its exposure as permafrost probably established quickly in this high-Arctic setting (Christiansen et al., 2002). Additionally, palsas developed in the low-lying areas since emergence. In addition, niveo-fluvial and niveo-aeolian sediment transport continues to modify the landscape downslope of snow patches (Christiansen, 1998b; Christiansen et al., 2002). At present, permafrost exists under all terrestrial surfaces.

\subsection{Application to other fjord valleys}

Recent studies have presented models for infilling of formerly glaciated fjord valleys from Greenland (Hansen, 2001, 2004), Norway (Nemec et al., 1999; Corner, 2006; Eilertsen et al., 2006; Hansen et al., 2009; Eilertsen et al., 2011), Canada (Marchand et al., 2013), Sweden (Plink-Björklund and Ronnert, 1999), and Germany (Winsemann et al., 2007). These investigations demonstrate that fjord valleys are primarily infilled during deglaciation and RSL fall, resulting in a complex stratigraphy, which can vary substantially between locations. However, recent studies also indicate that the underlying depositional regime controls are the same (Eilertsen et al., 2011). With the exception of the investigations in Greenland, these studies are restricted to non-permafrost environments. No previous studies have investigated ground ice or cryofacies in valley-fill deposits.

Previous studies have identified similar infilling patterns of valleys following regional deglaciation. Given similarities in sedimentary facies and landscape development, it is reason- able to expect that the aggradational history of permafrost is similar as well. This suggests that permafrost below the upper marine limit of large tributaries valleys throughout northeast Greenland is likely a Holocene phenomenon, with the exact age corresponding to the timing of subaerial exposure following marine transgression. These coarse-grained deposits contain an assemblage of cryofacies characteristics of ice-poor epigenetic permafrost.

\section{Summary and conclusions}

The valley-fill deposits in the Zackenberg lowlands formed during highstand and RSL fall following deglaciation, ca. 13 to $11 \mathrm{ka}$. The majority of the sedimentary deposits accumulated by the early Holocene, ca. $10 \mathrm{ka}$. During this period, the reduction in accommodation space during RSL fall and high glacial and paraglacial sediment yield resulted in rapid sedimentation and progradation of the delta. Permafrost began to aggrade in subaerial land surfaces following exposure, ca. $11 \mathrm{ka}$. In the Zackenberg lowlands, permafrost history is closely tied with delta progradation.

The following conclusions are drawn from this study:

- Following deglaciation, three distinct phases of delta formation are recognized in the sedimentary facies and cryofacies. The majority of the delta accumulated during the late Weichselian and early Holocene. Rapid sedimentation and delta progradation are attributed to high sediment yield from glaciers and glaciofluvial erosion and transport and the decline in accommodation space during sea-level fall.

- Permafrost in the Zackenberg lowlands is a Holocene phenomenon. The vertical distribution of cryofacies and absence of appreciable ground ice in frost-susceptible sediments indicates permafrost in the Zackenberg River delta deposits post-dates deglaciation. The onset of conditions conducive to permafrost aggradation is concurrent with subaerial exposure following RSL decline or delta progradation. The resultant epigenetic permafrost is ice poor, overall. The results of this investigation may have applications for other formerly glaciated fjord valleys in permafrost regions.

Data availability. The ground ice and stratigraphic data used in this paper can be obtained by contacting the corresponding author.

Competing interests. The authors declare that they have no conflict of interest.

Acknowledgements. This investigation was financed by the PAGE21 (Changing permafrost in the Arctic and its Global Effects in the 21 st Century) project - grant agreement number 292700 
under the EU Seventh Framework Programme. Additional funding was provided by the Centre for Permafrost (CENPERM) at the University of Copenhagen, funded by the Danish National Research Foundation (CENPERM DNRF1000) and by the Nordic Centre of Excellence, DEFROST (Impacts of a changing cryosphere depicting ecosystem-climate feedbacks from permafrost, snow, and ice). Christine Thiel received funding from the German Research Foundation (DFG grant TH1651/1-1). We thank Andrew Murray and Jan-Pieter Buylaert (Nordic Laboratory for Luminescence Dating) for their assistance with luminescence dating and in the preparation of this paper. We gratefully acknowledge the hospitality and assistance of the staff at the Zackenberg Ecological Research station. Special thanks to Ulrich Neumann (Kolibri Geoservices) and Jordan Mertes for their assistance during drilling in summer 2012. This paper has benefited from constructive comments from Michael Fritz and two anonymous reviewers. We would also like to thank the handling editor, Scott Lamoureux.

Edited by: S. Lamoureux

Reviewed by: M. Fritz and two anonymous referees

\section{References}

Aarseth, I.: Western Norwegian fjord sediments: age, volume, stratigraphy, and role as temporary depository during glacial cycles, Mar. Geol., 143, 39-53, doi:10.1016/S00253227(97)00089-3, 1997.

Alexanderson, H. and Murray, A. S.: Luminescence signals from modern sediments in a glaciated bay, NW Svalbard, Quat. Geochronol., 10, 250-256, doi:10.1016/j.quageo.2012.01.001, 2012.

Ballantyne, C. K.: Paraglacial geomorphology, Quaternary Sci. Rev., 21, 1935-2017, doi:10.1016/S0277-3791(02)00005-7, 2002.

Benn, D. I. and Evans, D. J. A.: Glaciers and Glaciation, 2 ed., Routledge, 816 pp., 2010.

Bennike, O. and Weidick, A.: Late Quaternary history around Nioghalvfjerdsfjorden and Jokelbugten, North-East Greenland, Boreas, 30, 205-227, 2001.

Bennike, O., Sorensen, M., Fredskild, B., Jacobsen, B. H., Bocher, J., Amsinck, S. L., Jeppesen, E., Andreasen, C., Christiansen, H. H., and Humlum, O.: Late quaternary environmental and cultural changes in the Wollaston Forland region, Northeast Greenland, Adv. Ecol. Res., 40, 45-79, doi:10.1016/S0065-2504(07)000037, 2008.

Buylaert, J. P., Murray, A. S., Thomsen, K. J., and Jain, M.: Testing the potential of an elevated temperature IRSL signal from K-feldspar, Radiat. Meas., 44, 560-565, doi:10.1016/j.radmeas.2009.02.007, 2009.

Buylaert, J.-P., Thiel, C., Murray, A. S., Vandenberghe, D. A. G., Yi, S., and Lu, H.: IRSL and post-IR IRSL residual doses recorded in modern dust samples from the Chinese Loess Plateau, Geochronometria, 38, 432, doi:10.2478/s13386-0110047-0, 2011.

Calmels, F., Froese, D. G., and Clavano, W. R.: Cryostratigraphic record of permafrost degradation and recovery following historic (1898-1992) surface disturbances in the Klondike re- gion, central Yukon Territory, Can. J. Earth Sci., 49, 938-952, doi:10.1139/e2012-023, 2012.

Christiansen, H. H.: "Little Ice Age" nivation activity in northeast Greenland, Holocene, 8, 719-728, doi:10.1191/095968398666994797, 1998a.

Christiansen, H. H.: Nivation forms and processes in unconsolidated sediments, NE Greenland, Earth Surf. Proc. Land., 23, 751-760, 1998b.

Christiansen, H. H. and Humlum, O.: Glacial history and periglacial landforms of the Zackenberg area, Northeast Greenland: preliminary results, Geogr. Tidsskr., 93, 19-29, 1993.

Christiansen, H. H., Bennike, O., Bocher, J., Elberling, B., Humlum, O., and Jakobsen, B. H.: Holocene environmental reconstruction from deltaic deposits in northeast Greenland, J. Quaternary Sci., 17, 145-160, doi:10.1002/jqs.665, 2002.

Christiansen, H. H., Åkerman, J. H., and Repelewska-Pekalowa, J.: Active layer dynamics in Greenland, Svalbard and Sweden, Extended abstract for the 8th International Permafrost Conference, 21-25 July 2003, Zurich, Switzerland, 2003.

Christiansen, H. H., Sigsgaard, C., Humlum, O., Rasch, M., and Hansen, B. U.: Permafrost and periglacial geomorphology at Zackenberg, Adv. Ecol. Res., 40, 151-174, doi:10.1016/S00652504(07)00007-4, 2008.

Corner, G. D.: A transgressive-regressive model of fjord-valley fill: stratigraphy, facies and depositional controls, in: Incised Valleys in Time and Space, edited by: Dalrymple, R. W., Leckie, D. A., and Tillman, R. W., Society of Sediment. Geol. (SEPM), 161178, 2006.

Eilertsen, R. S., Corner, G. D., Aasheim, O., Andreassen, K., Kristoffersen, Y., and Ystborg, H.: Valley-fill stratigraphy and evolution of the Målselv fjord valley, northern Norway, in: Incised-Valleys in Time and Space, edited by: Dalrymple, R. W., Leekie, D., and Tilman, R., 179-195, 2006.

Eilertsen, R. S., Corner, G. D., Aasheim, O. D. D., and Hansen, L.: Facies characteristics and architecture related to palaeodepth of Holocene fjord-delta sediments, Sedimentology, 58, 1784-1809, doi:10.1111/j.1365-3091.2011.01239.x, 2011.

Evans, D. J. A. and Benn, D. I.: A Practical Guide to the Study of Glacial Sediments, Routledge, London, United Kingdom, 280 pp., 2004.

Evans, D. J. A., Dowdeswell, J. A., Grobe, H., Niessen, F., Stein, R., Hubberten, H. W., and Whittington, R. J.: Late Quaternary sedimentation in Kejser Franz Joseph Fjord and the continental margin of East Greenland, in: Glacier-Influenced Sedimentation on High-Latitude Continental Margins, edited by: Dowdeswell, J. A. and O Cofaigh, C., The Geological Society of London, London, United Kingdom, 149-179, 2002.

Fleming, K. and Lambeck, K.: Constraints on the Greenland Ice Sheet since the Last Glacial Maximum from sea-level observations and glacial-rebound models, Quaternary Sci. Rev., 23, 1053-1077, doi:10.1016/j.quascirev.2003.11.001, 2004.

French, H. and Shur, Y.: The principles of cryostratigraphy, EarthSci. Rev., 101, 190-206, doi:10.1016/j.earscirev.2010.04.002, 2010.

Fuchs, M. and Owen, L. A.: Luminescence dating of glacial and associated sediments: review, recommendations and future directions, Boreas, 37, 636-659, doi:10.1111/j.15023885.2008.00052.x, 2008. 
Funder, S., Hjort, C., and Landvik, J. Y.: The Last Glacial Cycles in East Greenland, an Overview, Boreas, 23, 283-293, doi:10.1111/j.1502-3885.1994.tb00601.x, 1994.

Funder, S., Kjeldsen, K. K., Kjær, K. H., and Ó Cofaigh, C.: The Greenland Ice Sheet During the Past 300,000 Years: A Review, in: Developments in Quaternary Science, edited by: Ehlers, J., Gibbard, P. L., and Hughes, P. D., Elsevier, Amsterdam, the Netherlands, 699-713, 2011.

Gilbert, G. L., Kanevskiy, M., and Murton, J. B.: Recent Advances (2008-2015) in the Study of Ground Ice and Cryostratigraphy, Permafrost Periglac, 27, 377-389, doi:10.1002/ppp.1912, 2016.

Gilbert, R.: Sedimentary processes of Canadian Arctic fjords, Sediment. Geol., 36, 147-175, doi:10.1016/0037-0738(83)90007-6, 1983.

Hansen, B. U., Sigsgaard, C., Rasmussen, L., Cappelen, J., Hinkler, J., Mernild, S. H., Petersen, D., Tamstorf, M. P., Rasch, M., and Hasholt, B.: Present-Day Climate at Zackenberg, in: Advances in Ecological Research, edited by: Meltofte, H., Christensen, T. R., Elberling, B., Forchhammer, M. C., and Rasch, M., Academic Press, Oxford, UK, 111-149, 2008.

Hansen, L.: Landscape and Coast Development of a Lowland Fjord Margin following Deglaciation, East Greenland, Geogr. Ann. A, 83, 131-144, 2001.

Hansen, L.: Deltaic Infill of a Deglaciated Arctic Fjord, East Greenland: Sedimentary Facies and Sequence Stratigraphy, J. Sediment. Res., 74, 422-437, doi:10.1306/102703740422, 2004.

Hansen, L., Beylich, A., Burki, V., Eilertsen, R. S., Fredin, O. L. A., Larsen, E., Lyså, A., Nesje, A., Stalsberg, K., and Tønnesen, J. F.: Stratigraphic architecture and infill history of a deglaciated bedrock valley based on georadar, seismic profiling and drilling, Sedimentology, 56, 1751-1773, doi:10.1111/j.1365-3091.2009.01056.x, 2009.

Hasholt, B., Mernild, S. H., Sigsgaard, C., Elberling, B., Petersen, D., Jakobsen, B. H., Hansen, B. U., Hinkler, J., and Søgaard, H.: Hydrology and Transport of Sediment and Solutes at Zackenberg, in: Advances in Ecological Research, edited by: Meltofte, H., Christensen, T. R., Elberling, B., Forchhammer, M. C., and Rasch, M., Academic Press, Oxford, UK, 197-221, 2008.

Hjort, C.: A Glacial Chronology for Northern East Greenland, Boreas, 10, 259-274, doi:10.1111/j.1502-3885.1981.tb00487.x, 1981.

Humlum, O.: Holocene permafrost aggradation in Svalbard, in: Cryospheric Systems: Glaciers and Permafrost, edited by: Harris, C. and Murton, J. B., The Geological Society of London, London, United Kingdom, 119-129, 2005.

Jensen, L. M., Christiansen, T. R., and Schmidt, N. M.: Zackenberg Ecological Research Operations: 19th Annual Report 2013, DCE - Danish Centre for Environment and Energy, Aarhus University, Denmark, 130, 2014.

Kanevskiy, M., Jorgenson, T., Shur, Y., O’Donnell, J. A., Harden, J. W., Zhuang, Q., and Fortier, D.: Cryostratigraphy and Permafrost Evolution in the Lacustrine Lowlands of West-Central Alaska, Permafrost Periglac, 25, 14-34, doi:10.1002/ppp.1800, 2014.

Kneller, B. and Buckee, C.: The structure and fluid mechanics of turbidity currents: a review of some recent studies and their geological implications, Sedimentology, 47, 62-94, doi:10.1046/j.1365-3091.2000.047s1062.x, 2000.
Koch, L. and Haller, J.: Geological map of East Greenland 72-76 N.Lat. $(1: 250,000)$, in: Meddeleser om Grønland 3rd ed., 1-26, 1971.

Kokelj, S. V. and Burn, C. R.: Near-surface ground ice in sediments of the Mackenzie Delta, Northwest Territories, Canada, Permafrost Periglac, 16, 291-303, doi:10.1002/ppp.537, 2005.

Mackay, J. R.: The world of underground ice, Annals of the Association of American Geographers, 62, 1-22, doi:10.1111/j.14678306.1972.tb00839.x, 1972.

Marchand, J.-P., Buffin-Bélanger, T., Hétu, B., and St-Onge, G.: Stratigraphy and infill history of the glacially eroded Matane River Valley, eastern Quebec, Canada, Can. J. Earth Sci., 51, 105-124, doi:10.1139/cjes-2013-0054, 2013.

Miall, A.: The geology of fluvial deposits: sedimentary facies, basin analysis, and petroleum geology, Springer, 581 pp., 2006.

Miall, A. D.: Alluvial deposits, in: Facies models 4, edited by: James, N. P. and Dalrymple, R. W., Geological Association of Canada, St. John's, Canada, 105-138, 2010.

Murray, A. S. and Wintle, A. G.: Luminescence dating of quartz using an improved single-aliquot regenerative-dose protocol, Radiat. Meas., 32, 57-73, doi:10.1016/S1350-4487(99)00253-X, 2000.

Murray, A. S., Thomsen, K. J., Masuda, N., Buylaert, J. P., and Jain, M.: Identifying well-bleached quartz using the different bleaching rates of quartz and feldspar luminescence signals, Radiat. Meas., 47, 688-695, doi:10.1016/j.radmeas.2012.05.006, 2012.

Murton, J. B.: Ground Ice and Cryostratigraphy, in: Treatise on Geomorphology: Glacial and Periglacial Geomorphology, edited by: Giardino, R. and Harbor, J., Academic Press, San Diego, USA, 173-201, 2013.

Nemec, W.: Aspects of sediment movement on steep delta slopes, Coarse-grained deltas, 10, 29-73, 1990.

Nemec, W., Lønne, I. D. A., and Blikra, L. H.: The Kregnes moraine in Gauldalen, west-central Norway: anatomy of a Younger Dryas proglacial delta in a palaeofjord basin, Boreas, 28, 454-476, doi:10.1111/j.1502-3885.1999.tb00234.x, 1999.

Netto, R. G., Benner, J. S., Buatois, L. A., Uchman, A., Mangano, M. G., Ridge, J. C., Kazakauskas, V., and Gaigalas, A.: Glacial Environments, in: Trace Fossils as Indicators of Sedimentary Environments, edited by: Knaust, D. and Bromley, R. G., Elsevier, Amsterdam, the Netherlands, 299-327, 2012.

Nøhr-Hansen, H., Nielsen, L. H., Sheldon, E., Hovikoski, J., and Alsen, P.: Palaeogene deposits in North-East Greenland, Geol. Surv. Den. Greenl., 23, 61-64, 2011.

Ó Cofaigh, C., Lemmen, D. S., Evans, D. J. A., and Bednarski, J.: Glacial landform-sediment assemblages in the Canadian High Arctic and their implications for late Quaternary glaciation, Ann. Glaciol., 28, 195-201, doi:10.3189/172756499781821760, 1999.

Ó Cofaigh, C., Dowdeswell, J. A., Evans, D. J. A., Kenyon, N. H., Taylor, J., Mienert, A., and Wilken, M.: Timing and significance of glacially influenced mass-wasting in the submarine channels of the Greenland Basin, Mar. Geol., 207, 39-54, doi:10.1016/j.margeo.2004.02.009, 2004.

Pedersen, J. B. T., Kroon, A., and Jakobsen, B. H.: Holocene sea-level reconstruction in the Young Sound region, Northeast Greenland, J. Quaternary Sci., 26, 219-226, doi:10.1002/jqs.1449, 2011. 
Plink-Björklund, P. and Ronnert, L.: Depositional processes and internal architecture of Late Weichselian ice-margin submarine fan and delta settings, Swedish west coast, Sedimentology, 46, 215234, doi:10.1111/j.1365-3091.1999.sed195.x, 1999.

Pollard, W. H.: Distribution and characterization of ground ice on Fosheim Peninsula, Ellesmere Island, Nunavut, in: Environmental Response to Climate Change in the Canadian High Arctic, edited by: Garneau, M. and Alt, B. T., Geological Survey of Canada, Ottawa, Ontario, Canada, 207-233, 2000a.

Pollard, W. H.: Ground ice aggradation on Fosheim Peninsula, Ellesmere Island, Nunavut, in: Environmental Response to Climate Change in the Canadian High Arctic, edited by: Garneau, M. and Alt, B. T., Geological Survey of Canada, Ottawa, Ontario, Canada, 325-333, 2000b.

Pollard, W. H. and Bell, T.: Massive ice formation in the Eureka Sound Lowlands: a landscape model, Seventh International Conference on Permafrost, Yellowknife, Canada, 1998.

Reading, H. G.: Sedimentary environments: processes, facies and stratigraphy, Blackwell Science, Oxford, UK, 2009.

Rittenour, T. M.: Luminescence dating of fluvial deposits: applications to geomorphic, palaeoseismic and archaeological research, Boreas, 37, 613-635, doi:10.1111/j.1502-3885.2008.00056.x, 2008.
Stephani, E., Fortier, D., Shur, Y., Fortier, R., and Doré, G.: A geosystems approach to permafrost investigations for engineering applications, an example from a road stabilization experiment, Beaver Creek, Yukon, Canada, Cold Reg. Sci. Technol., 100, 20-35, doi:10.1016/j.coldregions.2013.12.006, 2014.

Thomsen, K. J., Murray, A. S., Jain, M., and Bøtter-Jensen, L.: Laboratory fading rates of various luminescence signals from feldspar-rich sediment extracts, Radiation Measurements, 43, 1474-1486, doi:10.1016/j.radmeas.2008.06.002, 2008.

Winkelmann, D., Jokat, W., Jensen, L., and Schenke, H. W.: Submarine end moraines on the continental shelf off NE Greenland Implications for Lateglacial dynamics, Quaternary Sci. Rev., 29, 1069-1077, doi:10.1016/j.quascirev.2010.02.002, 2010.

Winsemann, J., Asprion, U., Meyer, T., and Schramm, C.: Facies characteristics of Middle Pleistocene (Saalian) icemargin subaqueous fan and delta deposits, glacial Lake Leine, NW Germany, Sediment. Geol., 193, 105-129, doi:10.1016/j.sedgeo.2005.11.027, 2007. 